\title{
WestVirginiaUniversity
}

THE RESEARCH REPOSITORY @ WVU

West Virginia Agricultural and Forestry Experiment

Davis College of Agriculture, Natural Resources

Station Bulletins

And Design

$1-1-1988$

\section{Nutritive quality of warm season grasses in the Northeast}

\author{
R.L. Reid \\ G. A. Jung \\ D. W. Allinson
}

Follow this and additional works at: https://researchrepository.wvu.edu/ wv_agricultural_and_forestry_experiment_station_bulletins

\section{Digital Commons Citation}

Reid, R. L.; Jung, G. A.; and Allinson, D. W., "Nutritive quality of warm season grasses in the Northeast" (1988). West Virginia Agricultural and Forestry Experiment Station Bulletins. 699.

https://researchrepository.wvu.edu/wv_agricultural_and_forestry_experiment_station_bulletins/593 @ WVU. It has been accepted for inclusion in West Virginia Agricultural and Forestry Experiment Station Bulletins by an authorized administrator of The Research Repository@WVU. For more information, please contact ian.harmon@mail.wvu.edu. 

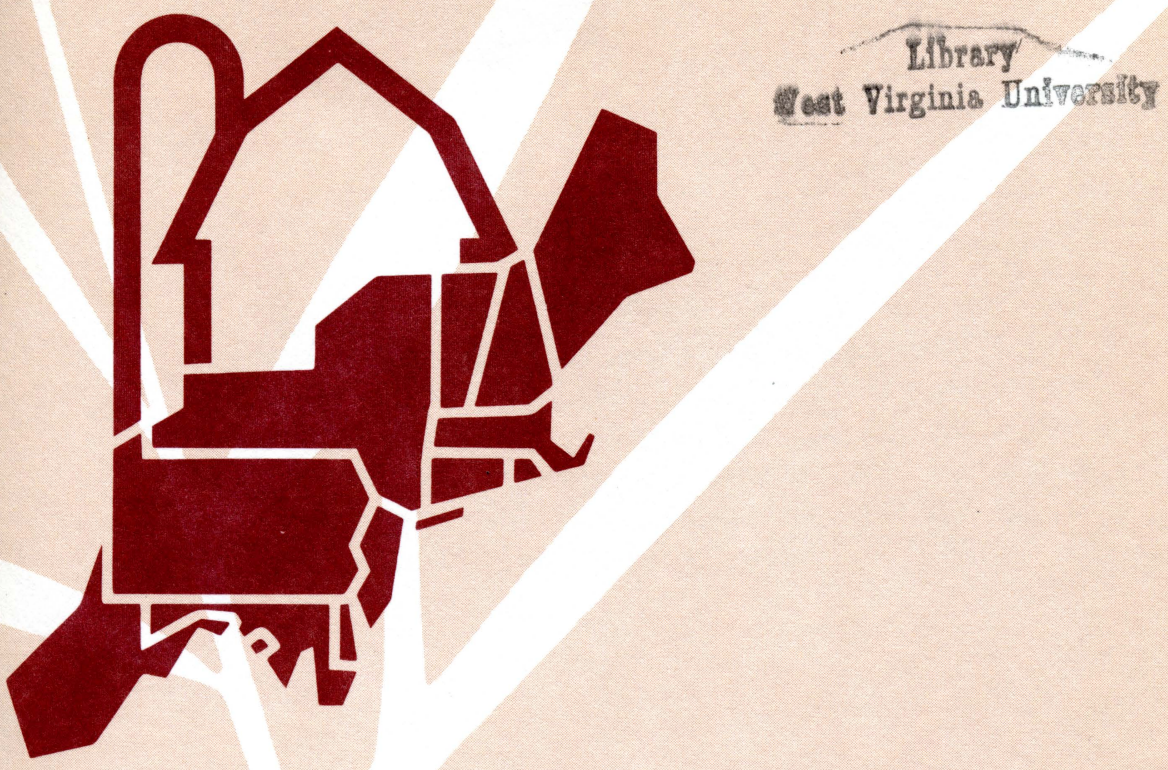

\section{NUTRITIVE QUALITY OF WARM SEASON GRASSES IN THE NORTHEAST}

Bulletin 699

July 1988

West Virginia University Agricultural and Forestry w Experiment Station 
Authors

R. L. Reid is professor, Division of Animal and Veterinary Sciences, West Virginia University; G.A. Jung is research agronomist with the USDA Regional Pasture Laboratories and is adjunct professor of agronomy, Pennsylvania State University; and D.W. Allinson is professor of forage crop physiology, University of Connecticut.

This Northeast Regional Publication is published with the approval of the director of the West Virginia Agricultural and Forestry Experiment Station as Contribution No. 8711 of the U.S. Regional and Pasture Research Laboratory.

\author{
West Virginia University \\ Agricultural and Forestry Experiment Station \\ College of Agriculture and Forestry \\ Robert H. Maxwell, Director \\ Morgantown
}




\section{Contents}

NE-114 Regional Technical Committee ii

Preface iii

List of Tables iv

List of Figures $\quad v$

Summary vi

Introduction $\quad 1$

Literature Review 3

-Chemical Composition 3

-In Vitro Digetibility 5

-Nutritive Quality 6

-Grazing Trials 7

Materials and Methods $\quad 11$

Results and Discussion $\quad 13$

-Chemical Composition 13

-In Vitro Evaluation $\quad 20$

-Nutritive Quality - Animal Trials 31

-Grazing Studies 39

$\begin{array}{ll}\text { Conclusions } & 43\end{array}$

Literature Cited 4 


\section{NE-114 Regional Technical Committee}

R.F. Hutton (Pennsylvania), T.P. Fairchild (New Hampshire), Administrative Advisors

Connecticut

Maine

Maryland

New Hampshire

New York

Ohio

Pennsylvania

Rhode Island

Vermont

West Virginia

SCS

USDA-Regional

Pasture Labs.

USDA-Beltsville

CR Representative
D.W. Allinson, ${ }^{*}$ R.A. Peters

R.G. Hall, ${ }^{*} M_{*}$ Mascianica

A.M. Decker, H.R. Badger,

W. Lessley

D.W. Koch, J.B. Mitchell

R.R. Seaney, ${ }_{*}$ D.L. Linscott

J.L. Parsons, ${ }^{*}$ R.W. Van Keuren

W.C. Stringer, ${ }^{*}$ R.H. Fox,

W.J. Kjelgaard, E.J. Partenheimer,

L.L. Wilson

R.C. Wakefield"

W.M. Murphy, G.M. Wood

R.L. Reid, W.B. Bryan,

J.A. Balasko, E.C. Prigge,

B.S. Baker

W.C. Sharp, J. Dickerson, ${ }^{*}$ M.

Testerman ${ }_{*}$ C. Gilbert, J. Oyler

G.A. Jung, W.L. Stout

R.F. Dudley*

C. Rumberg

* Official representatives, 1977-1986. 


\section{Preface}

The NE-114 Regional Project (Forage-Livestock Systems for Land with Soil and Site Limitations) was initiated in 1977 and will terminate, in its present form, in 1988. Specific objectives of the project were:

(a) to determine species and cultivars which are best suited to droughty or wet, acid soils that receive minimum or no chemical- physical alterations,

(b) to develop techniques using minimum or no tillage to establish adapted species on these sites,

(c) to assess the nutritive value of species grown under these conditions, and

(d) to develop forage utilization systems for ruminant production that make efficient use of restrictive sites and make maximum use of the growing season.

Among the species chosen for study in this project were the warm season perennial grasses. This publication will attempt to collate and interpret research conducted with these grasses under objectives (c) and (d) over approximately a 10 -year period. Other experiment station publications will review work done on the adaptation and establishment phases of the project. The report will include both material which has been published in journal form and unpublished data, and the authors wish to express their appreciation to workers in agricultural experiment stations and federal research institutions for permission to use unpublished results.

Preparation of this manuscript was the responsibility of R.L. Reid (West Virginia), G.A. Jung (USDA-ARS, Pennsylvania) and D.W. Allinson (Connecticut). The authors are indebted to Dr. R.F. Hutton (Pennsylvania) for his able guidance of this regional project during much of its existence, and to Dr. T.P. Fairchild (New Hampshire), the present Administrative Advisor to the Regional Technical Committee. 


\section{Tables}

1. Mean concentrations (dry basis), with standard deviations of means, of crude protein, neutral detergent fiber, acid detergent fiber and lignin in warm season grasses.

2. Mean concentrations (dry basis), with standard deviations of means, of elements in warm season grasses.

3. Mean concentrations (dry basis), with standard deviations of means, of microelements in warm season grasses.

4. Mean in vitro dry matter digestibilities, with standard deviations of means, of warm season grasses.

5. Mean in vitro DMD and chemical composition, with standard deviations of means, of individual warm season grasses.

6. Correlation coefficients between chemical components and in vitro DMD for all warm season grasses.

7. Effects of inoculum on mean in vitro dry matter digestibility values of warm season grasses from different locations.

8. Mean dry matter digestibility and dry matter and neutral detergent fiber intakes, with standard errors of the means, for sheep and cattle fed different classes of forage.

9. Significant regression equations between dry matter digestibility, intake and fiber components for forage classes fed to sheep and cattle. 


\section{Figures}

1. Rates of in-vitro dry matter disappearance of switchgrass (S) and perennial ryegrass ( $R$ ) substrates as influenced by source of inoculum (sheep and cattle), type of diet (switchgrass or ryegrass) and level of intake (ad libitum or restricted) of donor animal.

2. In-vivo dry matter digestibility coefficients for switchgrass and ryegrass hays fed to sheep and cattle compared to in-vitro coefficients with sheep or cattle as source of inoculum.

3. Rate of decline in dry matter digestibility of switchgrass hay by sheep and cattle with cutting date, compared to rates of decline of a warm season annual grass, cool season grass and a cool season legume.

4. Apparent retention of calcium, phosphorus and magnesium by cattle and sheep fed warm season grass hays harvested at different stages of maturity.

5. Frequency distributions of dry matter digestibilities of tropical and temperate grasses compared with distribution of values from warm season and cool season grasses in West Virginia feeding trials. 36

6. Frequency distributions of levels of intake of warm season and cool season grasses in West Virginia trials. 


\section{Summary}

Trials were conducted by a number of Northeast states to determine the nutritive quality of warm season perennial grasses grown on soils of limiting fertility. Major findings of the study were:

(1) Concentrations of nutrients such as $\mathbf{N}, \mathbf{P}$ and $S$ in the warm season grasses were generally low and of marginal adequacy to meet the requirements of growing or lactating beef cattle. Chemical composition varied with growth stage and plant part and, for certain components, there were indications of species and location differences.

(2) In vitro evaluations showed generally low IVDMD values, with higher quality of leaf than of stem. Results showed differences between stations in in vitro - in vivo relationships and indicated that in vitro methods applicable to cool season forages required modification for warm season grasses.

(3) Digestibility and intake trials with cattle and sheep showed that cattle utilized the warm season grasses more efficiently than did sheep. In 78 feeding trials with cattle, mean dry matter digestibility and intake values were 60.6 percent and $89.8 \mathrm{~g} / \mathrm{kg} \mathrm{BW}^{.75} /$ day, respectively, compared with values of 54.5 precent and $65.7 \mathrm{~g} / \mathrm{kg} \mathrm{BW}^{.73} / \mathrm{day}$ in 61 trials with sheep.

Intake levels of warm season grasses, particularly by cattle, were higher than would have been predicted from NDF concentrations and digestibility values. This may explain, in part, the good rates of liveweight gain observed with cattle in grazing trials. The results also suggest modifications to existing theories of intake regulation in ruminants.

(4) Regression analysis between animal responses (digestibility, intake) and fiber components (ADF, NDF) showed different relationships between warm season grasses and cool season grasses and legumes, as well as between cattle and sheep. Individual fiber components were not reliable estimators of either digestibility or intake.

(5) Grazing trials in Pennsylvania and West Virginia showed generally good performance (ADG, gain per hectare, grazing days) by growing cattle and cow-calf units on warm season grass pastures. System approaches suggest grazing of permanent cool season hill pastures in spring, followed by rotational grazing of warm season grasses at high stocking density from mid- to late summer, with return of animals to cool season pastures in the fall. 


\section{NUTRITIVE QUALITY OF WARM SEASON GRASSES IN THE NORTHEAST}

R.L. Reid, G.A. Jung and D.W. Allinson

\section{Introduction}

While the native warm season grasses have been grazed by indigenous ruminant animals in the Great Plains region for centuries, their use for pasture production in the north-central and north-eastern states is quite recent. The main advantages of the grasses are their summer growth habit, providing forage when temperate grasses such as Kentucky bluegrass (Poa pratensis L.) have become semi-dormant, and their ability to grow on soils of low fertility and to use soil moisture efficiently.

By the same token, they share the disadvantage of all tropical or $\mathrm{C}_{4}$ grasses in that their nutritive quality for livestock is lower than that of temperate $\left(\mathrm{C}_{3}\right)$ species. This appears to be related to higher fiber and lower crude protein concentrations in the warm season grasses and, possibly, to limiting concentrations of some essential minerals. Part of the problem associated with low livestock production on tropical pastures is, however, related to direct effects of the tropical environment on composition of the plant and on grazing behavior and metabolism of the animal. High nutritive quality of forage, as measured by digestibility of energy, is attained under cool environmental conditions, as long as radiation and temperature are high enough for herbage growth. For this reason, warm season annual and perennial grasses have higher digestibilities when grown at northern latitudes than in the south (Reid and Jung, 1982). 
Some of the questions to be asked relating to the feeding value of these grasses are, therefore:

(1) Do $\mathrm{C}_{4}$ grasses grown in a temperate environment have quality characteristics (e.g. composition, digestibility, intake) significantly different from those of temperate grasses or legumes grown under the same environmental conditions or of tropical species in, for example, the south-east states?

(2) Do forages adapted to soils of low fertility, with low levels of fertilization and management, contain adequate concentrations of essential nutrients such as nitrogen or minerals for optimal utilization by grazing livestock, or is supplementation required?

(3) Are laboratory analytical methods developed for the evaluation of temperate grasses and legumes equally applicable to warm season grasses?

(4) What modifications in grazing management are required to utilize fully the different growth patterns and structures of native warm season grasses, and to integrate these effectively with the management of permanent temperate pastures on the marginal land areas of the Northeast?

The research reported in this bulletin addresses certain of these problems. 


\section{Literature Review}

The main differences between $\mathrm{C}_{3}$ and $\mathrm{C}_{4}$ grasses lie in (a) leaf anatomy, (b) photosynthetic pathways, (c) photorespiration, (d) ${ }^{13} \mathrm{C}$ to ${ }^{12} \mathrm{C}$ ratios. The subject has been reviewed by Edwards and Walker (1983) and Jones (1985). The fundamental differences in leaf structure (Kranz anatomy) and metabolism of $\mathrm{C}_{4}$ grasses result in marked differences in composition and nutritional quality of tropical and temperate forages (Moore and Mott, 1973; Minson, 1981a; Norton, 1982). Environmental conditions exert a strong effect on composition and quality of the plant (Deinum and Dirven, 1974; Deinum, 1983; Wilson, 1982, 1984). Differences in the anatomy and composition of $\mathrm{C}_{4}$ grasses result in slower rates of degradation of fiber components by bacteria and fungi in the rumen (Akin, 1982, 1986; Wilson, 1985), and lower digestibility by cattle and sheep (Minson and McLeod, 1970; Minson, 1981a). Under tropical or subtropical conditions, pastures based on $\mathrm{C}_{4}$ grasses are generally considered to provide no more than a maintenance level of nutrition for grazing animals. The observation that native warm season grasses in pasture systems in the northern United States frequently support good rates of gain in grazing cattle therefore requires a better understanding of the composition and utilization of these grasses by ruminant animals.

\section{Chemical Composition}

It is well established that tropical grasses contain relatively high concentrations of fiber and low levels of protein (Payne, 1966; Butterworth, 1967; Bailey, 1973; Moore and Mott, 1973; Reid et al., 1979; Norton, 1982). Norton (1982), in a review, noted concentrations of $33.9,30.3,26.0$ and 25.3 percent crude fiber in tropical grasses, tropical legumes, temperate grasses and temperate legumes, respectively. Moore and Mott (1973) observed that while the ranges of crude fiber, acid detergent fiber (ADF) and lignin concentration were similar in tropical and temperate grasses, the concentration of neutral detergent fiber (NDF) was consistently higher in tropical forages. The effects of temperature on cell wall development were examined by Ford et al. (1979); with increasing temperature, leaf NDF concentrations in temperate species (Lolium perenne cv.S 24) increased, while in tropical species (Panicum maximum var. trichoglume) NDF levels decreased. The decrease was due to a decline in cellulose concentration, while hemicellulose and lignin contents increased. Bailey (1973) concluded that the tropical grasses contained higher concentrations of 
leaf cellulose than temperate grasses, with similar levels of hemicellulose.

The increase in fiber components with maturation of $\mathrm{C}_{4}$ grasses has been shown to be either curvilinear (Bredon and Horrell, 1961) or linear (Johnson et al., 1973; Reid et al., 1979). In a management study with switchgrass (Panicum virgatum L.) and Caucasian bluestem [Bothriochloa caucasica (Trin.) C.E. Hubbard], Anderson and Matches (1983) found linear increases of 1.4 percentage units NDF per week for both grasses cut at a stubble height of $8 \mathrm{~cm}$. Lignin concentrations increase with maturation and Akin $(1982,1986)$ has shown that warm season grasses contain higher concentrations of low molecular weight, saponifiable phenolic compounds such as p-coumaric acid than do cool season species. These compounds may reduce the activity of bacteria and fungi which break down fiber in the rumen and thereby limit cell wall degradation.

Minson (1981a), in an analysis of the literature, found that 22 percent of tropical grass values for crude protein concentration were less than 6 percent, compared with only 6 percent of values with temperate forages. He considered that crude protein levels of less than 6 to 8 percent in forage would result in depressed intake by the animal. The low levels of protein in $\mathrm{C}_{4}$ grasses were attributed by Wilson and Haydock (1971) to a deficiency of soil nitrogen, an increased top growth and a depletion of soil nutrients. Typical protein values were reported for switchgrass grown under different water regimes in Texas (Koshi et al., 1982). In unharvested grass, crude protein concentrations declined from 10.8 percent in late June to 4.3 percent in mid-November; increased clipping frequency increased protein levels. Newell and Moline (1978), in Nebraska, found a decrease in crude protein concentration of first growth switchgrass from $\mathbf{1 7 . 5}$ percent in early June to 8.4 percent in mid-July; regrowth harvests from early July to early October contained between 7 and 10 percent crude protein. In Missouri studies (Anderson and Matches, 1983), crude protein concentrations in switchgrass and Caucasian bluestem decreased 1.6 and 1.0 percentage units per week, respectively, in first harvest forage. Ranges in protein levels were 5 to 13 percent for Caucasian bluestem first growth and 8 to 16 percent for switchgrass; comparable values in regrowth material were 3 to 6 percent, and 5 to 9 percent, respectively.

There are clear differences in the concentration of certain minerals between tropical and temperate forages (Fleming, 1973; Reid et al., 1979; Norton, 1982). A review by Norton (1982) showed lower levels of $\mathrm{Ca}$ and $\mathrm{P}$, and higher concentrations of $\mathrm{Mg}$ and $\mathrm{Cu}$, in tropical than in temperate grasses, with similar concentrations of $\mathrm{Na}$, 
$\mathrm{Zn}$ and Co. Reid et al. (1979) found significant differences in the mineral concentrations of tropical grasses due to genus, species and variety of forage and observed variable effects of maturation on element levels. Phosphorus concentrations in unharvested switchgrass grown in Texas decreased from 0.23 percent in June to 0.12 percent in November (Koshi et al., 1982). At the latter levels, P deficiency signs in grazing animals may be observed (Reid, 1980). In a growth chamber study, Balasko and Smith (1971) noted a decrease in concentrations of $\mathrm{N}, \mathrm{Ca}, \mathrm{P}$ and $\mathrm{K}$ in switchgrass as temperature increased, with little effect on concentrations of $\mathrm{Mg}, \mathrm{Na}, \mathrm{Al}, \mathrm{Fe}, \mathrm{Sr}, \mathrm{Cu}$ or $\mathrm{Zn}$. Nitrogen fertilization increased the levels of all elements at all temperatures, with the exception of $\mathrm{Na}, \mathrm{Al}, \mathrm{B}$ and $\mathrm{Cu}$.

In another greenhouse study, Friedrich et al (1977) reported low $S$ concentrations ( $<0.10$ percent) in switchgrass; the concentration of $S$ in leaf and stem tissue increased with $S$ fertilization and high rates of $\mathrm{S}$ increased the level of $\mathrm{N}$ in the leaf. Effects of soils and fertilization on the mineral composition and utilization of temperate and tropical forages, and the health of livestock, are reviewed by Reid and Jung (1974) and Reid and Horvath (1980).

\section{In Vitro Digestibility}

The in vitro technique provides the most accurate laboratory measure of forage digestibility (Barnes, 1973; Minson, 1981b; Marten, 1981; Reid and Klopfenstein, 1983) and has been widely used in defining the potential feeding value of temperate and tropical forages. Minson (1981b) cited mean residual standard deviation (RSD) values of \pm 2.3 (rumen fluid) and \pm 2.6 (cellulase) in the prediction of forage dry matter digestibility, compared with RSD's of \pm 4.1 for lignin, \pm 4.8 for $\mathrm{ADF}$ and \pm 7.6 for NDF. Variations in the technique may include the addition of $\mathrm{N}$ sources to the rumen inoculum when protein levels in the forage are low, as is frequently the case with $\mathrm{C}_{4}$ grasses.

Some reports have indicated differences in in vivo-in vitro digestibility relationships among classes of forage. Long (1967), McLeod and Minson (1969) and Olubajo et al. (1974) reported that in vitro digestibility coefficients were less than in vivo values for tropical grasses. Reid et al. (1973) noted a general trend for the two stage in vitro procedure to underestimate digestibility coefficients of tropical grasses fed to sheep, and obtained significant differences between in vivo and in vitro digestibility regressions associated with different forage species. Vogel et al. (1984), however, found no significant differences between in vivo and in vitro digestibility coefficients of switchgrass strains when supplementary urea was added to the in vitro rumen fluid. 
Nebraska workers (Ward et al., 1984) found that a switchgrass strain selected for high IVDMD gave significantly better average daily gains (ADG) and liveweight gains per hectare in yearling beef cattle on pasture than did a low IVDMD strain or the control cultivar Pathfinder. In Missouri trials, Anderson and Matches (1983) reported IVDMD values from 30 to 48 percent for regrowth switchgrass and Caucasian bluestem. In vitro DMD of first harvest forage was less than 65 percent. They concluded that IVDMD of whole plant warm season grasses may not adequately reflect the response of grazing cattle, due either to selective grazing or to poor prediction relationships between IVDMD and dry matter digestibility.

Nelson (1980) has discussed the main sources of variability (forage species, sample preparation, inoculum microbial population, laboratory procedures) influencing in vivo-in vitro relationships in southern forages. He suggested that in vitro methods developed with temperate grass species required modification for tropical forages. Minson (1981b) concluded that use of the pepsin-cellulase method avoided some of the problems of the rumen fluid-pepsin approach and Roughan and Holland (1977) obtained high correlations between in vivo dry matter digestibility of temperate and tropical forages and cellulase digestion following extraction with neutral detergent solution. Good relationships between in vivo and cellulase digestibility, with cultures from Trichoderma reesei Simmons, were reported by Bughrara and Sleper (1986) for a number of temperate forage species. The technique is at present being evaluated with warm season grasses (D.A. Sleper, personal communication).

\section{Nutritive Quality}

The best criterion of feeding value of a forage is, obviously, some direct measurement of animal response in the form of liveweight gain or milk or wool production. Since feeding trials are lengthy and require large numbers of animals, their use in forage evaluation is often impractical. The most frequently used criteria are measurements of digestibility of energy (or dry matter) and intake obtained in shorter term trials. Animal response is best related to the product of digestible energy (percent) and level of intake. While there is generally a significant positive relationship between digestibility of energy and the consumption of forages by ruminants (Hodgson et al., 1977; Voigtländer and Kühbauch, 1978; Minson, 1982), the relationship is not consistent (Van Soest, 1965; Minson, 1982) and it is therefore necessary to consider energy digestibility and intake as independent factors. 
The digestibility of energy (DE) or dry matter digestibility (DMD) of tropical forages is lower than that of temperate species. Minson and McLeod (1970) showed a mean difference of 12.8 percentage units between populations of tropical and temperate grasses, a difference which has been attributed by Minson (1981a) to the higher temperatures at which tropical grasses are grown rather than to inherent differences between the grasses. Similar differences have been shown for voluntary intake, apparently relating to the higher levels of fiber in tropical grasses and longer retention times in the reticulorumen.

Relatively few measurements have been made of the digestibility and intake of the native warm season grasses in the United States. Horn and Jackson (1979) fed a number of Old World bluestems to calves and recorded DMD's ranging from 55.0 to 70.5 percent for different cuttings. Vogel et al. (1984) tested three strains of switchgrass, including those selected for high and low IVDMD, in digestibility and intake trials with sheep. They found no differences between strains in in vivo DMD, fiber digestibility or dry matter intake. Dry matter digestibility coefficients of the strains ranged from 49.0 to 50.8 percent. Trials with Kleberg bluestem (Dicanthium annulatum) hays fed to steers in Texas (Pacheco et al., 1983) gave low DMD values (mean 41.8 percent) and correspondingly low intakes. In a summary of forage evaluation studies in the S-45 regional project, Moore et al. (1980) reviewed digestibility and intake data for temperate perennial, temperate annual, tropical perennial and tropical annual forages fed as hays to sheep and cattle. Dry matter digestibilities of the warm season perennial grasses tended to be lower ( 49.6 to 58.8 percent) than for the temperate perennials, but intakes were relatively high (79.5 to $97.9 \mathrm{~g} / \mathrm{kg}$ body weight ${ }^{.75}$ ) and comparable to those of the other forage groups.

\section{Grazing Trials}

The problems and principles of utilizing tropical grasses in grazing systems for livestock production have been reviewed (Stobbs, 1971, 1976; Shaw and Bryan, 1976; Wilson and Minson, 1980; 't Mannetje, 1974,1982 ) and no attempt will be made to discuss an extensive literature. As stated by 't Mannetje (1982), the main limitations in tropical regions are "availability of green feed for at least half the year in seasonally dry regions and low nutritive value during most of the period of active pasture growth," Much the same problems apply to livestock production under range conditions in the western United States. Use of native warm season grasses for summer grazing can, however, supp- 
lyvaluable supplementary pastures for cattle production in areas of the Great Plains and Corn Belt with limiting soil and climate conditions.

Grazing responses are measured as ADG, liveweight gain per hectare and animal grazing days. Dwyer and Elder (1964) reported carrying capacities for Woodward sand bluestem (Andropogon hallii Hack.) and Caddo switchgrass pastures of 141 animal grazing days, with ADG for bred heifers of 0.58 and $0.45 \mathrm{~kg}$, respectively. In Missouri, Blackwell switchgrass and Caucasian bluestem gave ADG for steers of 0.64 and $0.54 \mathrm{~kg}$ over 113 and 98 days for the two grasses (Matches et al., 1977). Results indicated that tall fescue (Festuca arundinacea Schreb.)-Caucasian bluestem systems gave a higher carrying capacity than fescue-switchgrass. In South Dakota, Krueger and Curtis (1979) obtained ADG's for yearling steers of 0.93 and $0.70 \mathrm{~kg}$ for switchgrass and big bluestem (Andropogon gerardii Vitm.), respectively, over a 31 to 42 -day grazing period. Steer grazing days per hectare were 199 for big bluestem and 160 for switchgrass. During the same period, steers grazing Holt indiangrass [Sorghastrum nutans (L.) Nash] gained $1.08 \mathrm{~kg}$ per day, with 111 steer days of grazing. Liveweight gain per hectare averaged $146 \mathrm{~kg}$ for switchgrass, $138 \mathrm{~kg}$ for big bluestem and $119 \mathrm{~kg}$ for indiangrass. Steers grazing switchgrass in Iowa gained $225 \mathrm{~kg}$ per hectare compared with $148 \mathrm{~kg}$ per hectare on regrowth smooth brome (Bromus inermis Leyss.) (Wedin and Fruehling, 1978).

Where warm season grasses are used in integrated grazing systems, utilizing cool season pastures in spring followed by warm season species in summer, improvements in ADG and output per hectare are generally observed, as reported by Conard and Clanton (1963) in Nebraska and Matches et al. (1977) in Missouri. Burns et al. (1984) compared an intensive grazing system with yearling steers on fescueCoastal bermudagrass [Cynodon dactylon (L.) Pers.] as a control with grazing of switchgrass, flaccidgrass (Pennisetum flaccidum Griseb.) and Pennisetum orientale Rich. Over a three-year period, ADG's on fescue-bermudagrass were $0.58 \mathrm{~kg}$ compared with $0.90 \mathrm{~kg}$ on flaccidgrass and $0.96 \mathrm{~kg}$ on switchgrass at a stocking rate of 8 to 10 steers per hectare. An interesting feature was the significantly better performance of cattle on flaccidgrass and switchgrass than on Coastal bermudagrass. In this study in North Carolina, grazing on the tall warm season grasses was initiated at a much earlier growth stage than is generally used. Kaiser et al. (1986) have compared a variety of season long grazing systems involving combinations of several cool season and warm season grasses in southern Illinois. Preliminary data showed highest steer gains of $.45 \mathrm{~kg}$ per day on a sequence of smooth bromebig bluestem-smooth brome, to a low gain of $0.19 \mathrm{~kg}$ per day on a tall 
fescue-indiangrass-tall fescue combination, with heavy endophyte infestation of the fescue.

While a number of studies on grazing behavior of livestock on tropical pastures have been made in Australia (Stobbs, 1973; Chacon and Stobbs, 1976; Chacon et al., 1978; Arnold, 1981; Ludlow et al., 1983), little work has been done with the native warm season grasses in this country. Fisher et al. (1987) found that steers with esophageal cannulae grazed predominantly on leaf material in the upper canopy of switchgrass and flaccidgrass pastures. The IVDMD of grazed herbage was 69 and 70 percent for switchgrass and flaccidgrass, respectively, compared with whole plant IVDMD's of 53 and 63 percent. In Oklahoma, Forbes and Coleman (1987) studied the effect of different levels of herbage mass on ingestive behavior of cattle on Asiatic bluestem (Bothriocloa spp.) pastures. Intake increased and grazing time decreased, with no change in biting rate, with increasing herbage mass. Availability of herbage had no effect on in vitro OMD. Moore et al. (1987) showed selective behavior by cattle within a limpograss (Hemarthria altissima)-American jointvetch (Aeschynomene americana) pasture canopy in Florida. Steers preferentially selected legume in the upper canopy layer and, as percentage legume in the upper canopy increased, biting rate decreased, with no change in intake per bite. A different approach has been reviewed by Jones (1981), who used the ${ }^{13} \mathrm{C} /{ }^{12} \mathrm{C}$ ratio in feces of animals grazing mixed $\mathrm{C}_{3}$ (tropical legume, temperate grass and legume) and $\mathrm{C}_{4}$ (tropical grass) pastures to determine the relative amounts of $C_{3}$ and $C_{4}$ species selected. 
[Blank Page in Original Bulletin] 


\section{Materials and Methods}

Plant samples for quality analyses were grown and collected in different states under a wide range of soil, environmental and management conditions. Species analyzed were predominantly switchgrass and big bluestem, with smaller numbers of little bluestem, indiangrass, Plains bluestem and Caucasian bluestem samples at different sites. The grasses were generally grown on soils of low fertility (low $\mathrm{pH}$, available $\mathrm{P}, \mathrm{K})$. In initial trials in Connecticut, plants at different stages of maturity were collected from uncultivated roadside sites; in Ohio, at the other extreme, warm season grass stands were grown on soils of moderate fertility, with annual treatment with $224 \mathrm{~kg}$ per ha of $0-20-20$ and $168 \mathrm{~kg}$ per ha ammonium nitrate in late May. In Pennsylvania and West Virginia, for the most part, stands were established on low fertility soils and grasses were treated with a small amount of nitrogen (56 $\mathrm{kg}$ per hectare) in the spring. Samples were also obtained from Soil Conservation Service Plant Materials Centers in New York (Big Flats), Kentucky (Quicksand) and New Jersey (Cape May), and from private farms in Pennsylvania.

Grass samples were collected at a range of growth stages from vegetative to full bloom, primarily in the first growth cycle, although a number of regrowth samples are included. A number of cultivars of the main grass species were used, and these have been combined within species in the section on chemical analysis and in vitro evaluation. Cultivars are defined in the discussion of animal responses and grazing trials. In most cases, whole plant samples were analyzed; in some studies, plants were separated into leaf and stem fractions and results of these comparisons will be considered independently.

Chemical analysis of plant samples was by accepted procedures (AOAC, 1980). Neutral detergent fiber and ADF concentrations were determined according to Goering and Van Soest (1970). Lignin was determined either as acid-detergent or as potassium permanganate lignin. Element analysis was by atomic absorption spectrophotometry, $\mathbf{P}$ by a colorimetric procedure and $\mathrm{S}$ by a Leco induction furnace method. The in vitro analysis was a modification of the Tilley and Terry (1963) two-stage procedure. Chemical and in vitro data are taken from published sources (Griffin et al., 1980; Griffin and Jung, 1981; Taylor and Allinson, 1981; Vona, 1982; Morris et al., 1982; Griffin and Jung, 1983; Vona et al., 1984; Balasko et al., 1984; Reid and Jung, 1985; Jung et al., 1985; Vona, 1986; Jung et al., 1987) and from unpublished material (from D.W. Allinson, J.A. Balasko, G.A. Jung, R.L. Reid, R.W. Van Keuren). 
Warm season grasses were fed in animal evaluation trials in Pennsylvania and West Virginia. In Pennsylvania, switchgrass and big bluestem hays were fed to wether lambs in digestibility and intake trials (Griffin et al., 1980). Soybean meal was provided as a protein supplement. In cooperative trials between the USDA Pasture Research Laboratories and West Virginia University, hays harvested in Pennsylvania, New York, Kentucky and New Jersey were fed to beef cows and sheep in West Virginia (Vona et al., 1984), with measurement of digestibility, intake and mineral utilization. Further trials have been conducted with cultivars of switchgrass and big bluestem, with flaccidgrass, and with switchgrass and big bluestem hays under S fertilization (R.L. Reid and G.A. Jung, unpublished data). Trial procedures are described in detail in the cited publications.

Grazing trials with the warm season grasses were conducted in Pennsylvania and West Virginia (Jung et al., 1978; Fairbairn et al., 1985; Reid and Jung, 1985; Jung et al., 1985; Jung, 1986; Jung et al., 1987). Trials were designed to examine the yield and persistence of different warm season grasses under grazing, to determine the nutritional quality of grazed herbage under different management systems, to study the grazing behavior of animals on warm season grass pastures, and to determine the effect of integrating the use of warm season grasses in summer with utilization of cool season pastures in spring and fall to increase livestock production on marginal land areas. Again, details of experimental procedures are given in the appropriate publications.

Analysis of data (correlation, regression, analysis of variance) was run by standard procedures (Steel and Torrie, 1980; SAS, 1985). In view of the various possible confounding effects (climate, soils, management, cultivars, growth stage) on chemical and in vitro analyses, no attempt was made to analyze differences between states statistically. Interpretation of possible location effects is therefore speculative. In considering data from animal evaluation and grazing trials the statistical analyses used in individual studies will be employed. 


\section{Results and Discussion}

\section{Chemical Composition}

Chemical analysis (crude protein, NDF, ADF, lignin, minerals) was performed on a total of 531 warm season grass samples produced in Connecticut, Kentucky, New Jersey, New York, Ohio, Pennsylvania and West Virginia. The samples are identified by the state in which the grasses were grown, rather than by the source of publication of results (e.g. samples grown in Kentucky, New Jersey and New York were fed and analyzed in West Virginia). Analytical data for concentrations of crude protein, NDF, ADF and lignin are summarized by location in Table 1, and mineral data in Tables 2 and 3.

The mean crude protein concentration in 369 warm season grasses from all locations was 7.60 percent, with a range from 1.8 to 15.3 percent. The NRC (1984) requirements for lactating beef cows $(450$ $\mathrm{kg}$ ) are given as 9.9 percent; the earlier (NRC, 1976) recommendation for growing-finishing steers ( $350 \mathrm{~kg}$, ADG $0.9 \mathrm{~kg}$ ) was 10.0 percent. The "average" warm season grass would not therefore meet the protein requirements of cattle with a high nutrient requirement and would require protein supplementation.

It should be noted, however, that 25 percent of samples (early growth stages) had an average protein concentration of 9.8 percent and that the samples analyzed represented whole plant material. Taylor and Allinson (1981) reported mean crude protein concentrations of 5.6 vs. 2.7 percent for leaf vs. stem in big bluestem, and of 6.3 vs. 3.6 percent in indiangrass grown in Connecticut. Similarly, Griffin and Jung (1983), in Pennsylvania, gave protein values for leaf and stem of 9.1 and 4.8 percent, respectively, in switchgrass, and of 10.8 and 5.2 percent, respectively, in big bluestem. Grazing cattle preferentially select leaf material (Fisher et al., 1987; Moore et al., 1987) and protein consumption would therefore be expected to be markedly higher than indicated by whole plant analysis. The somewhat lower mean protein concentration of samples from Connecticut than from other states may relate to the sites of collection in earlier studies (Taylor and Allinson, 1981).

Mean NDF and ADF concentrations of whole plant samples for all states were 73.7 and 41.8 percent, respectively, with relatively minor variations between locations. Concentrations of NDF ranged from 61.1 to 86.2 percent, and of ADF from 27.1 to 52.7 percent. Lignin concentrations averaged 6.0 percent, with a range of values from 2.9 to 9.8 percent. These levels of cell wall components are similar to those cited 
Table 1. Mean Concentrations (Dry Basis), with Standard Deviations of Means, of Crude Protein, Neutral Detergent Fiber, Acid Detergent Fiber and Lignin in Warm Season Grasses. ${ }^{\text {a }}$

\begin{tabular}{|c|c|c|c|c|c|c|c|c|}
\hline Location & $\begin{array}{l}\text { Crude } \\
\text { protein }\end{array}$ & & $\mathrm{NDF}$ & & $\mathrm{ADF}$ & & Lignin & \\
\hline & $--\infty-\infty-\infty$ & --- & --- & $---\%$ & 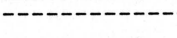 & --- & --- & --- \\
\hline Connecticut & $5.73 \pm 2.64$ & $(93)^{b}$ & $73.0 \pm 4.1$ & $(88)$ & $42.9 \pm 5.0$ & $(88)$ & $5.9 \pm 1.5$ & $(88)$ \\
\hline Kentucky & $8.25 \pm 3.13$ & (4) & $74.5 \pm 4.1$ & $(4)$ & $44.3 \pm 5.8$ & (4) & $5.1 \pm 2.2$ & (4) \\
\hline New Jersey & $8.87 \pm 3.95$ & (4) & $74.9 \pm 4.9$ & (4) & $40.8 \pm 6.1$ & $(4)$ & $5.9 \pm 1.4$ & (4) \\
\hline New York & $8.40 \pm 2.12$ & (8) & $77.0 \pm 4.0$ & (8) & $44.0 \pm 4.4$ & $(8)$ & $5.7 \pm 1.1$ & $(8)$ \\
\hline Ohio & $9.39 \pm 2.25$ & $(18)$ & $73.6 \pm 1.8$ & $(18)$ & $41.9 \pm 2.0$ & (18) & --- & \\
\hline Pennsylvania & $8.46 \pm 1.83$ & (125) & $74.5 \pm 3.6$ & $(67)$ & $43.8 \pm 4.0$ & $(25)$ & $7.0 \pm 1.1$ & $(16)$ \\
\hline West virginia & $7.76 \pm 3.02$ & $(117)$ & $73.6 \pm 4.5$ & $(79)$ & $39.4 \pm 4.7$ & $(73)$ & $6.0 \pm 1.7$ & $(31)$ \\
\hline All & $7.60 \pm 2.76$ & $(369)$ & $73.7 \pm 4.5$ & $(268)$ & $41.8 \pm 4.9$ & $(220)$ & $6.0 \pm 1.6$ & (151) \\
\hline
\end{tabular}

a All grass species combined.

b Figures in parenthesis are numbers of samples analyzed. 
by Moore and Mott (1973) for tropical grasses. As would be expected, individual studies reported considerably higher levels of fiber components in the stem than in the leaf (Taylor and Allinson, 1981; Griffin and Jung, 1983).

As a percentage of the diet, NRC $(1976,1984)$ recommends Ca and $P$ concentrations of 0.28 and 0.23 percent, respectively, for the lactating beef cow, and 0.25 and 0.22 percent for the growing-finishing steer. Comparison of these values with mean concentrations of elements in the warm season grasses (Table 2) of 0.30 percent $\mathrm{Ca}(414$ samples) and 0.17 percent $P$ (412 samples) indicates that $P$ levels may be marginal or deficient in meeting animal requirements. Lowest $\mathbf{P}$ concentrations were noted in grasses grown in Connecticut, Kentucky and West Virginia. Morris et al. (1982) grew a number of species (switchgrass, big bluestem, little bluestem, indiangrass, Caucasian bluestem) and cultivars of warm season grass on a low P soil in Pennsylvania and determined yield and composition responses to $P$ fertilizer. They concluded that cultivars differed in their ability to grow on low $\mathbf{P}$ soils, that warm season grasses apparently had a lower $\mathrm{P}$ requirement for growth than cool season species, and that the warm season grasses gave higher yields and had lower $P$ concentrations than cool season species on low P soils. They found no significant relationship between forage $\mathbf{P}$ concentration and either crude protein level or IVDMD values.

For all forages analyzed in the present study, correlation coefficients were calculated between composition and quality measurements (Table 6). The correlations between $P$ concentration and crude protein levels $(+0.74)$ and IVDMD values $(+0.76)$ were highly significant and much higher than the correlation coefficients obtained with $\mathrm{Ca}$ ( +0.33 and +0.25 , respectively). Taylor and Allinson (1981) in Connecticut observed much higher levels of $\mathrm{Ca}$ in the leaf than in the stem, with small differences in $\mathbf{P}$ concentrations, a finding confirmed for P by Griffin and Jung (1983) in Pennsylvania. Selective grazing of leaf material by cattle would not, therefore, be expected to improve $\mathbf{P}$ nutrition appreciably. The results suggest that $\mathbf{P}$ supplementation of animals grazing warm season grass pastures would be a desirable practice [see also Nutritive Quality section for balance data by Vona et al. (1984)].

Tropical grasses appear to contain higher concentrations of $\mathrm{Mg}$ than temperate species. Norton (1982), for example, cited mean concentrations of 0.36 and 0.40 percent $\mathrm{Mg}$ in tropical grasses and legumes, respectively, compared with concentrations of 0.18 and 0.29 percent $\mathrm{Mg}$ in cool season grasses and legumes. The requirement for dietary $\mathrm{Mg}$ by beef cattle has been given as 0.10 percent (NRC, 1984), 
Table 2. Mean Concentrations (Dry Basis), with Standard Deviations of Means, of Elements in Warm Season Grasses.

\begin{tabular}{|c|c|c|c|c|c|c|c|c|c|c|}
\hline Location & Calcium & & \multicolumn{2}{|c|}{ Phosphorus } & \multicolumn{2}{|l|}{ Magnesium } & \multicolumn{2}{|l|}{ Potassium } & \multicolumn{2}{|l|}{ Sulfur } \\
\hline Connecticut & $0.25 \pm 0.10$ & $(96)^{b}$ & $0.15 \pm 0.06$ & $(96)$ & $0.08 \pm 0.04$ & $(96)$ & $1.04 \pm 0.49$ & $(96)$ & --- & \\
\hline Kentucky & $0.31 \pm 0.09$ & (29) & $0.14 \pm 0.05$ & (29) & $0.14 \pm 0.06$ & (29) & $1.05 \pm 0.43$ & (29) & $0.13 \pm 0.04$ & (4) \\
\hline New Jersey & $0.32 \pm 0.04$ & (4) & $0.23 \pm 0.06$ & (4) & $0.28 \pm 0.07$ & (4) & $1.89 \pm 0.53$ & (4) & $0.14 \pm 0.03$ & (4) \\
\hline New York & $0.36 \pm 0.07$ & (19) & $0.22 \pm 0.07$ & (19) & $0.25 \pm 0.07$ & (19) & $1.46 \pm 0.49$ & (19) & $0.14 \pm 0.01$ & (8) \\
\hline Ohio & $0.31 \pm 0.04$ & (18) & $0.24 \pm 0.03$ & (18) & $0.27 \pm 0.08$ & (18) & $1.33 \pm 0.14$ & (18) & --- & \\
\hline Pennsylvania & $0.29 \pm 0.07$ & $(122)$ & $0.19 \pm 0.05$ & $(120)$ & $0.22 \pm 0.06$ & $(122)$ & $1.42 \pm 0.36$ & $(86)$ & $0.14 \pm 0.02$ & (58) \\
\hline West Virginia & $0.32 \pm 0.10$ & $(126)$ & $0.16 \pm 0.06$ & $(126)$ & $0.13 \pm 0.04$ & $(126)$ & $1.21 \pm 0.42$ & (126) & $0.13 \pm 0.04$ & $(82)$ \\
\hline All & $0.30 \pm 0.09$ & $(414)$ & $0.17 \pm 0.06$ & $(412)$ & $0.16 \pm 0.08$ & $(414)$ & $1.23 \pm 0.45$ & $(378)$ & $0.14 \pm 0.03$ & (156) \\
\hline
\end{tabular}

a All grass species combined.

b Figures in parenthesis are numbers of samples analyzed. 
with a range from 0.05 to 0.25 percent, the latter level being appropriate for lactating cows. A mean concentration of 0.16 percent $\mathrm{Mg}$ in 414 samples of warm season grass indicates a general adequacy of this element, although values for individual locations varied widely. Values from Connecticut ( 0.08 percent) were particularly low and may be compared with mean concentrations of 0.13 percent in West Virginia and 0.22 percent in Pennsylvania, although, as indicated, differences between locations are probably confounded and need to be interpreted with care.

It is interesting to note that grass tetany has not been observed in animals on warm season grasses. Mayland and Grunes (1979) speculate that a higher availability of $\mathrm{Mg}$ in $\mathrm{C}_{4}$ grasses may be related to the form and distribution of $\mathrm{Mg}$ in the plant. In balance trials with cattle and sheep fed a range of switchgrass and big bluestem hays in West Virginia, Vona et al. (1984) found that both animal species remained in positive $\mathrm{Mg}$ balance at all stages of maturity of the hays.

Potassium concentrations were quite low (mean 1.23 percent for 378 samples) and concentrations were correlated highly and positively with crude protein (0.78), IVDMD (0.82) and P (0.82). The suggested requirement $(\mathrm{NRC}, 1984)$ for beef cattle is 0.65 percent $K$ in the diet. Sulfur concentrations were also consistently low, with a mean level of 0.14 percent $S$ and little variation in concentration between locations. The suggested requirement for $S$ by beef cattle is 0.10 percent of the diet (NRC, 1984), although it is the opinion of the authors that this recommendation is too low, since animal responses have been noted in cattle and sheep to supplementation with $\mathrm{S}$ above this level (Rees et al., 1974; Goodrich et al., 1978).

Microelement concentrations in the warm season grasses (Table 3) averaged $6.8 \mathrm{ppm}$ for $\mathrm{Cu}, 35.5 \mathrm{ppm}$ for $\mathrm{Zn}, 103 \mathrm{ppm}$ for $\mathrm{Mn}$ and 91 ppm for $\mathrm{Fe}$, with high standard deviations and considerable variability among locations. Markedly higher $\mathrm{Cu}$ and $\mathrm{Zn}$ concentrations were recorded for grasses grown in Connecticut than for samples from other locations. Recommended requirements for beef cattle (NRC, 1984) are $8 \mathrm{ppm} \mathrm{Cu}, 30 \mathrm{ppm} \mathrm{Zn}, 40 \mathrm{ppm} \mathrm{Mn}$ and $50 \mathrm{ppm}$ Fe. While the amounts of $\mathrm{Cu}$ required by ruminant animals are significantly influenced by concentrations of Mo (not analyzed) and S, it can be suggested that the $\mathrm{Cu}$ concentrations of warm season grasses from most locations may be marginal or deficient. It is of interest that Norton (1982) reported generally higher concentrations of $\mathrm{Cu}$ in tropical grasses $(15 \mathrm{ppm} \mathrm{Cu})$ compared with temperate grasses $(6 \mathrm{ppm} \mathrm{Cu})$.

Apart from Connecticut, concentrations of $\mathrm{Zn}$ in the warm season grasses among locations ranged from mean values of $18.2 \mathrm{ppm}$ (New Jersey) to $27.3 \mathrm{ppm}$ (Pennsylvania). While these values are lower than 
Table 3. Mean Concentrations (Dry Basis), with Standard Deviations of Means, of Microelements in Warm Season Grasses. ${ }^{a}$

\begin{tabular}{|c|c|c|c|c|c|c|c|c|c|c|}
\hline Location & Copper & \multicolumn{3}{|c|}{ Zinc } & \multicolumn{2}{|c|}{ Manganese } & \multicolumn{4}{|c|}{ Iron } \\
\hline Connecticut & $12.3 \pm 4.2$ & $(93)^{b}$ & $66.8 \pm 40.4$ & $(93)$ & $86 \pm 67$ & (93) & 119 & \pm & 68 & (93) \\
\hline Kentucky & $5.8 \pm 1.7$ & (29) & $22.0 \pm 8.9$ & (29) & $63 \pm 32$ & (29) & 90 & \pm & 94 & (29) \\
\hline New Jersey & $5.0 \pm 0.8$ & (4) & $18.2 \pm 4.0$ & (4) & $64 \pm 23$ & (4) & 100 & \pm & 34 & (4) \\
\hline New York & $6.9 \pm 1.2$ & (19) & $22.5 \pm 5.2$ & (19) & $126 \pm 47$ & (19) & 233 & \pm & 166 & (19) \\
\hline Ohio & $4.8 \pm 1.3$ & (18) & $22.5 \pm 4.0$ & (18) & $69 \pm 13$ & (18) & 57 & \pm & 4 & (18) \\
\hline Pennsylvania & $5.4 \pm 1.3$ & $(86)$ & $27.3 \pm 11.7$ & $(86)$ & $112 \pm 49$ & $(104)$ & 73 & \pm & 35 & $(86)$ \\
\hline West Virginia & $4.4 \pm 1.4$ & $(126)$ & $25.4 \pm 6.4$ & $(126)$ & $121 \pm 53$ & $(126)$ & & \pm & 50 & $(127)$ \\
\hline All & $6.8 \pm 4.0$ & (375) & $35.5 \pm 28.0$ & $(375)$ & $103 \pm 56$ & (393) & 91 & \pm & 76 & $(376)$ \\
\hline
\end{tabular}

a All grass species combined.

b Figures in parenthesis are numbers of samples analyzed. 
the recommended dietary concentration of $30 \mathrm{ppm} \mathrm{Zn}$ for beef cattle, it is not clear whether marginal levels of $\mathrm{Zn}$ have any appreciable effect on animal performance. Recent cooperative studies between Pennsylvania and West Virginia (Reid et al., 1987) showed no growth or intake responses by lambs fed alfalfa to increases in $\mathrm{Zn}$ concentration, from mean values of $18 \mathrm{ppm}$ in the basal diet to $41 \mathrm{ppm} \mathrm{Zn}$ in alfalfa with foliar application of $\mathrm{Zn}$.

Concentrations of $\mathrm{Mn}$ and $\mathrm{Fe}$ in the warm season grasses from all locations appeared to be adequate to meet the requirements of beef animals.

The chemical composition of different species of warm season grass was also examined (Table 5), although no statistical analysis was applied, due to the problem of confounding factors. There appeared to be relatively little overall difference between species in their concentration of crude protein or cell wall components (NDF, ADF, lignin), although certain element concentrations did show fairly large differences. Switchgrass, for example, contained markedly higher concentrations of $\mathrm{Mg}(0.21$ percent) than the other grass species ( 0.10 to 0.13 percent). Caucasian bluestem contained low concentrations of $\mathrm{Cu}$. Under controlled conditions at individual locations, Griffin et al. (1980) noted higher fiber (NDF, ADF) concentrations in big bluestem than in switchgrass harvested on the same date (July 29). Griffin and Jung (1983) separated leaf and stem tissue of the two species and found that leaves of big bluestem contained more protein but less NDF than switchgrass leaves; stem tissue of big bluestem contained lower concentrations of NDF but a higher level of lignin than stem tissue of switchgrass.

Some species and cultivar differences in crude protein and $\mathrm{P}$ concentrations of switchgrass, big bluestem, little bluestem, Caucasian bluestem and indiangrass were reported by Morris et al. (1982) in Pennsylvania. For a number of cultivars of switchgrass and big bluestem harvested at equivalent growth stages in Pennsylvania, New York, Kentucky and New Jersey, Vona et al. (1984) found no differences in levels of crude protein, NDF, ADF or elements. Jung et al. (1985), however, reported significant differences in the protein concentration of cultivars of switchgrass and big bluestem grown in mixed stands in Pennsylvania.

While the situation with regard to compositional and quality differences between species and cultivars of warm season grasses in the Northeast requires further investigation, the potential for selection of grasses of higher quality has been demonstrated by the work of Vogel et al. (1984) in Nebraska. 


\section{In Vitro Evaluation}

In vitro evaluations of warm season grasses were run at three locations (Connecticut, Pennsylvania, West Virginia), and overall means of IVDMD values are given, by location, in Table 4 and, by species, in Table 5. Correlation coefficients between IVDMD and chemical components are summarized in Table 6 . The in vitro data include published results of Griffin et al. (1980), Griffin and Jung (1981), Taylor and Allinson (1981), Morris et al. (1982), Vona (1982), Griffin and Jung (1983), Balasko et al. (1984), Jung et al. (1985), Reid and Jung (1985), Vona (1986) and Jung et al. (1987), and unpublished results of D.W. Allinson, J.A. Balasko, G.A. Jung and L.C. Vona-Davis.

As seen in Table 4, the mean IVDMD of 289 samples of warm season grass was quite low, 49.0 percent, with a range from 41.6 percent in Connecticut evaluations to 54.2 percent in West Virginia trials. For samples collected in 1978 at different harvest dates, Taylor and Allinson (1981) reported a higher IVDMD for leaf than for stem samples, mean values of 46.3 vs. 34.4 percent for big bluestem, and 55.1 vs. 40.4 percent for indiangrass, respectively. Similarly, Griffin and Jung (1983) obtained IVDMD's of 60.8 vs. 52.4 percent for leaf and stem, respectively, of big bluestem, and of 61.2 vs. 51.3 percent for leaf and stem of switchgrass, as mean values for several harvest dates. Both publications noted declines in IVDMD with maturation of the grasses. Griffin and Jung (1983) found that the decrease in IVDMD of stem tissue was much higher than that of the leaf; at the stage of early head emergence, mean IVDMD's of leaf and stem for both grasses were 60 and 50 percent, respectively.

There was some indication of possible species differences in IVDMD values (Table 5), although again the results are subject to confounding. Mean IVDMD's of switchgrass, big bluestem, indiangrass and Plains bluestem were similar at about 50 percent, with higher means of Caucasian bluestem and lower values for little bluestem.

Within locations, Taylor and Allinson (1981) found in one year that indiangrass had a higher IVDMD than switchgrass, big bluestem and little bluestem; in another year, the IVDMD of indiangrass was higher than that of big bluestem. Using material from established plots, Allinson (unpublished data) found no differences in IVDMD of switchgrass and big bluestem harvested on the same date in 1980 and 1982; in 1981, indiangrass had a higher IVDMD than switchgrass. Griffin et al. (1980) in Pennsylvania reported higher IVDMD estimates for big bluestem than for switchgrass, and a later study (Griffin and Jung, 1983) showed that leaf tissue of big bluestem averaged 3.1 percentage units higher in IVDMD than switchgrass at the stage of early head emergence. Jung et al. (1985) found significant cultivar differen- 
Table 4. Mean In Vitro Dry Matter Digestibilities, with Standard Deviations of Means, of Warm Season Grasses. ${ }^{a}$

\begin{tabular}{lc}
\hline Location & \multicolumn{2}{c}{ IVDMD } \\
\hline & \multicolumn{2}{c}{$\%$} \\
Connecticut & $41.6 \pm 10.5 \quad(96)^{\mathrm{b}}$ \\
Kentucky & --- \\
New Jersey & -- \\
New York & --- \\
Ohio & --- \\
Pennsylvania & $50.0 \pm 4.7 \quad(67)$ \\
West Virginia & $54.2 \pm 9.2(126)$ \\
All & $49.0 \pm 10.4 \quad(289)$ \\
\hline
\end{tabular}

a All grass species combined.

b Figures in parenthesis are numbers of samples analyzed. 
Table 5. Mean In Vitro DMD And Chemical Composition, with Standard Deviations of Means, of Individual Warm Season Grasses.

\begin{tabular}{|c|c|c|c|c|c|c|c|c|c|c|c|c|}
\hline Measurement & Switchgrass & & $\begin{array}{l}\text { Big } \\
\text { bluestem }\end{array}$ & & $\begin{array}{l}\text { Little } \\
\text { bluestem }\end{array}$ & & Indiangrass & & $\begin{array}{l}\text { Caucasian } \\
\text { bluestem }\end{array}$ & & $\begin{array}{l}\text { Plains } \\
\text { bluestem }\end{array}$ & \\
\hline In vitro DMD, 8 & $50.0 \pm 9.4$ & $(123)^{\mathrm{b}}$ & $49.0 \pm 10.4$ & $(74)$ & $36.2 \pm 7.3$ & $(22)$ & $47.3 \pm 10.3$ & $(36)$ & $57.2 \pm 7.5$ & $(27)$ & $51.1 \pm 8.5$ & (7) \\
\hline Crude protein, $\%$ & $7.82 \pm 2.63$ & $(180)$ & $7.86 \pm 2.88$ & $(98)$ & $5.80 \pm 2.48$ & $(24)$ & $6.58 \pm 2.73$ & $(37)$ & $7.99 \pm 2.81$ & $(25)$ & $8.74 \pm 2.07$ & (5) \\
\hline NDF， \& & $73.2 \pm 4.5$ & $(104)$ & $73.8 \pm 4.9$ & $(75)$ & $75.4 \pm 2.0$ & $(21)$ & $73.5 \pm 3.0$ & $(35)$ & $73.9 \pm 5.4$ & $(26)$ & $76.8 \pm 6.5$ & (7) \\
\hline$A D F, ~ \%$ & $40.5 \pm 4.9$ & $(79)$ & $43.1 \pm 5.5$ & $(57)$ & $43.8 \pm 3.3$ & $(21)$ & $42.9 \pm 4.0$ & $(34)$ & $39.9 \pm 4.2$ & $(24)$ & $40.6 \pm 2.9$ & (5) \\
\hline Lignin, \% & $6.0 \pm 1.5$ & (58) & $6.6 \pm 1.8$ & $(39)$ & $5.9 \pm 1.2$ & $(19)$ & $5.2 \pm 1.2$ & $(25)$ & $6.1 \pm 1.7$ & $(10)$ & --- & \\
\hline Calcium, \% & $0.32 \pm 0.09$ & $(169)$ & $0.26 \pm 0.08$ & $(127)$ & $0.33 \pm 0.10$ & $(27)$ & $0.28 \pm 0.10$ & $(58)$ & $0.32 \pm 0.07$ & $(26)$ & $0.29 \pm 0.09$ & (7) \\
\hline Phosphorus, $\&$ & $0.19 \pm 0.06$ & $(166)$ & $0.16 \pm 0.06$ & $(122)$ & $0.13 \pm 0.05$ & $(30)$ & $0.16 \pm 0.06$ & $(60)$ & $0.20 \pm 0.05$ & $(27)$ & $0.19 \pm 0.08$ & (7) \\
\hline Magnesium, : & $0.21 \pm 0.09$ & (169) & $0.13 \pm 0.07$ & $(127)$ & $0.10 \pm 0.05$ & $(27)$ & $0.10 \pm 0.04$ & $(58)$ & $0.13 \pm 0.03$ & $(26)$ & $0.12 \pm 0.06$ & (7) \\
\hline Potassium, $q$ & $1.29 \pm 0.45$ & (151) & $1.21 \pm 0.44$ & (109) & $0.88 \pm 0.40$ & $(27)$ & $1.16 \pm 0.41$ & $(58)$ & $1.37 \pm 0.36$ & $(26)$ & $1.37 \pm 0.59$ & (7) \\
\hline Sulfur, : & $0.14 \pm 0.03$ & $(73)$ & $0.12 \pm 0.03$ & $(43)$ & -- & & $0.13 \pm 0.02$ & (7) & $0.14 \pm 0.03$ & $(26)$ & $0.19 \pm 0.04$ & (7) \\
\hline Copper, ppm & $7.3 \pm 4.0$ & $(151)$ & $6.1 \pm 3.5$ & $(109)$ & $8.8 \pm 3.6$ & $(27)$ & $8.0 \pm 5.0$ & $(55)$ & $3.8 \pm 1.3$ & $(26)$ & $4.4 \pm 1.7$ & (7) \\
\hline Zinc, ppm & $28.3 \pm 16.9$ & (151) & $37.9 \pm 32.2$ & $(109)$ & $35.7 \pm 19.4$ & $(27)$ & $57.3 \pm 40.5$ & $(55)$ & $23.4 \pm 3.4$ & $(26)$ & $24.0 \pm 3.8$ & (7) \\
\hline Manganese, ppm & $93 \pm 48$ & $(160)$ & $107 \pm 53$ & $(118)$ & $153 \pm 92$ & $(27)$ & $113 \pm 58$ & $(55)$ & $75 \pm 21$ & $(26)$ & $97 \pm 31$ & (7) \\
\hline Iron, $\mathrm{ppm}$ & $99 \pm 89$ & $(152)$ & $84 \pm 68$ & $(109)$ & $99 \pm 58$ & $(27)$ & $76 \pm 62$ & $(55)$ & $89 \pm 58$ & $(26)$ & $122 \pm 98$ & (7) \\
\hline
\end{tabular}

a All states combined

b Figures in parenthesis are numbers of samples analyzed. 
ces in the IVDMD of switchgrass and big bluestem, although the effect was not consistent between years. Morris et al. (1982) reported that the Old World bluestems had higher IVDMD values than big or little bluestems, switchgrass or indiangrass.

Examination of correlation coefficients between IVDMD and chemical components of warm season grasses (Table 6) shows that the highest correlations were obtained with crude protein $(0.76), P(0.76)$ and $\mathrm{K}(0.82)$ concentrations in the forage. Coefficients with NDF, $\mathrm{ADF}$ and lignin concentrations were $-0.55,-0.70$ and -0.63 , respectively.

While the high correlation of IVDMD with $\mathrm{K}$ concentration may be fortuitous and related to a high association between levels of $K$, crude protein and $P$ within the plant, the relationships of IVDMD with crude protein and $\mathrm{P}$ concentrations are of considerable interest. A high association of IVDMD with crude protein has not generally been demonstrated for temperate forages. In studies with tropical forages, however, Bredon et al. (1963) showed a high correlation between protein concentration and dry matter and organic matter digestibility. Reid et al. (1979) obtained a significant correlation coefficient of 0.47 between IVDMD and crude protein concentration of a large number of tropical grasses grown in Uganda, although the relationship was not as high as that between IVDMD and the cell wall components. In this study, however, the protein concentrations were markedly higher than those observed for the warm season grasses. In the trials conducted with warm season grasses grown on low P soils in Pennsylvania (Morris et al., 1982), a significant positive correlation was noted between IVDMD and crude protein concentrations, but not with $P$.

It should be noted that the in vitro techniques used in different locations were not uniform, and that in some studies a source of $\mathrm{N}$ was added to the fermentation mixture; inorganic $\mathrm{P}$ is a normal component of the buffer solution. Effects of these elements on degradation of the cell wall components may therefore be modified. The high positive correlations of IVDMD with crude protein and $P$ concentrations, which are inherently low in the warm season grasses, appear to warrant further investigation.

Different relationships between IVDMD (or in vivo DMD) and levels of cell wall fractions are noted in the literature, and relationships appear to be influenced by type of forage. The Van Soest system (1965, 1982) predicates that digestibility is best related to ADF concentration, or the ratio of lignin to ADF, while intake is better related to level of NDF. These relationships were originally developed for temperate forages. Moore and Mott (1973) found that lignin was the best single predictor of the digestibility of Florida grasses, while Kayongo-Male 
Table 6. Correlation Coefficients Between Chemical Components and In Vitro DMD for All Warm Season Grasses.

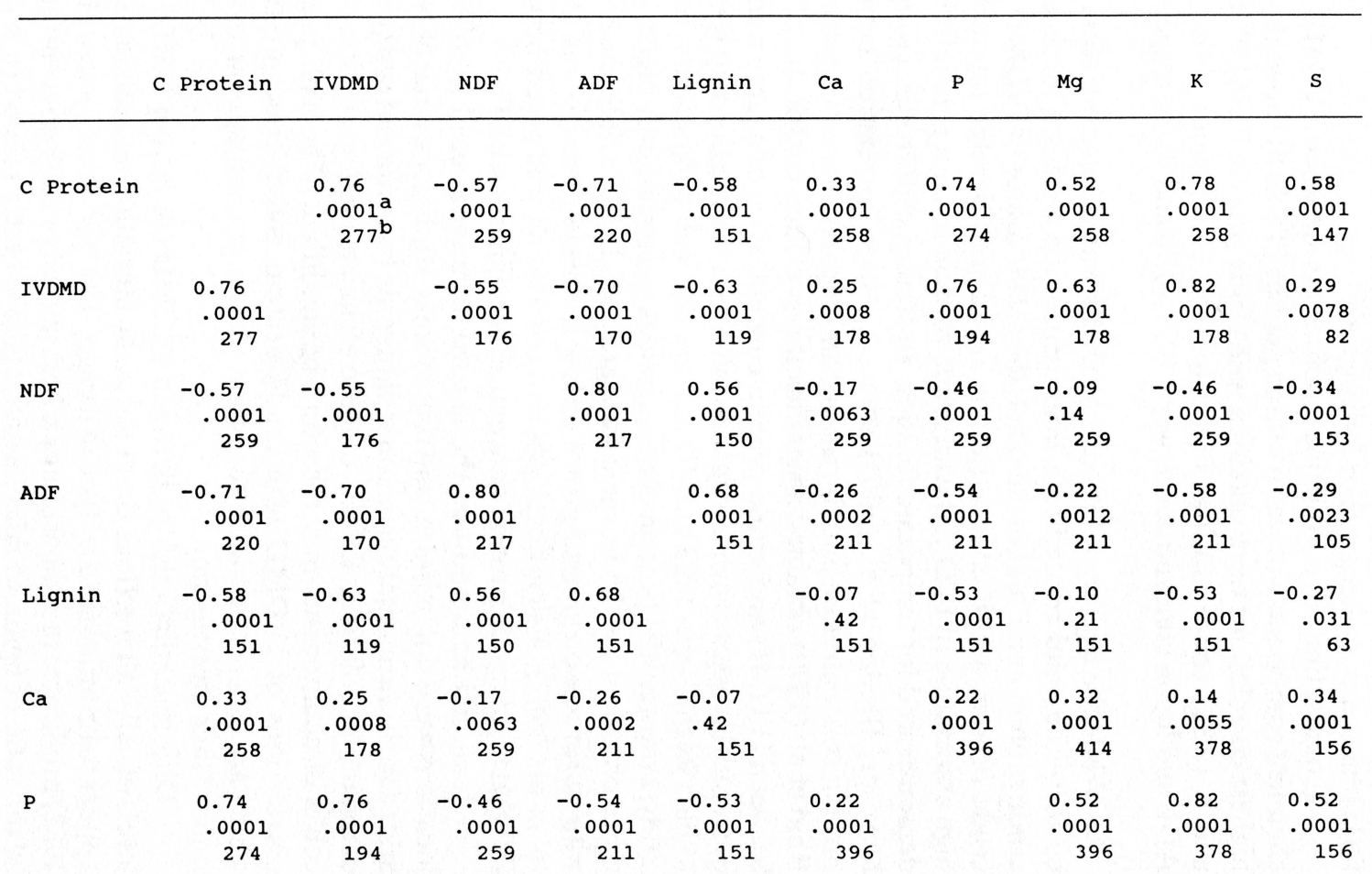


Table 6. Continued

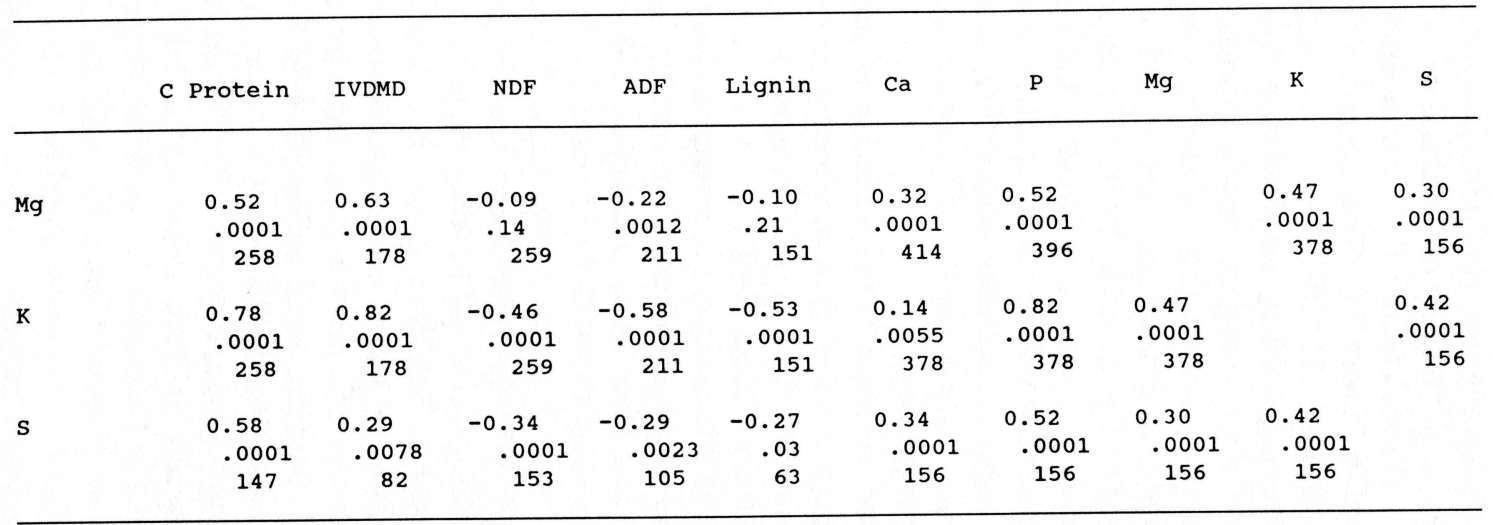

a $\quad \mathrm{P}<.0001$

b Number of samples 
et al. (1972) observed that ADF gave the highest correlation with IVDMD in a population of grasses in Puerto Rico. For a range of tropical grasses in Uganda, the highest correlations of IVDMD with single cell wall fractions were with NDF $(-0.72)$ and lignin $(-0.68)$, compared with a coefficient of -0.55 with ADF concentration (Reid et al., 1979). Rather similarly, Abrams et al. (1983) obtained a better correlation between organic matter digestibility and NDF than with ADF concentration in a population of tropical grass hays in Florida.

The present study shows that, of the cell wall fractions, the IVDMD of warm season grasses was best related to their ADF concentration, followed by lignin and by NDF. The nature of the correlations, however, tends to support a conclusion that no single chemical component determined would serve as a particularly good predictor of IVDMD. Relationships between digestibility, intake and chemical composition of warm season grasses will be discussed further in the section on Nutritive Quality.

An unresolved question at the initiation of this regional warm season grass project was whether in vitro techniques could be applied equally to the evaluation of $\mathrm{C}_{3}$ and $\mathrm{C}_{4}$ forages. The results obtained have not resolved the problem. In Pennsylvania, Griffin et al. (1980) found that the IVDMD technique underestimated in vivo DMD values for switchgrass and big bluestem hays fed to sheep by an averge of 17 percentage units. In a later study (Jung et al., 1985) the IVDMD of control switchgrass samples which had been fed to beef cows in West Virginia (Vona et al., 1984) was shown to be 10.0 percentage units lower than in vivo $\mathrm{DMD}$ values with the grass at the jointing stage, and 21.0 percentage units lower at the heading stage.

G.A. Jung and J.A. Balasko (unpublished data) made comparative in vitro evaluations of warm season and cool season grasses and legumes sampled at specific growth stages from the adaptation trials in 1979 and 1980. Samples were collected at Milesburg and Huntingdon, Pennsylvania; Reedsville, West Virginia; Connecticut and Rhode Island. Samples were digested with inocula from steers fed a warm season grass hay or from steers and a dairy cow fed alfalfa (Medicago sativa L.) in Pennsylvania; in West Virginia, an inoculum from sheep fed a warm season grass hay was used. A summary of results is given in Table 7. It can be noted that, when cool season and warm season forages were harvested at an equivalent stage of maturity, IVDMD's of the warm season grasses were consistently lower than those of cool season species. Further, while diet source (warm season vs. cool season grass hay) did not appear to have much effect on IVDMD values, considerable variability was noted between individual animals and individual runs. Consistently, highest IVDMD levels for 
Table 7. Effects of Inoculum on Mean In Vitro Dry Matter Digestibility Values of Warm Season Grasses from Different Locations. Analysis Run at USDA Pasture Research Labs., Pa.

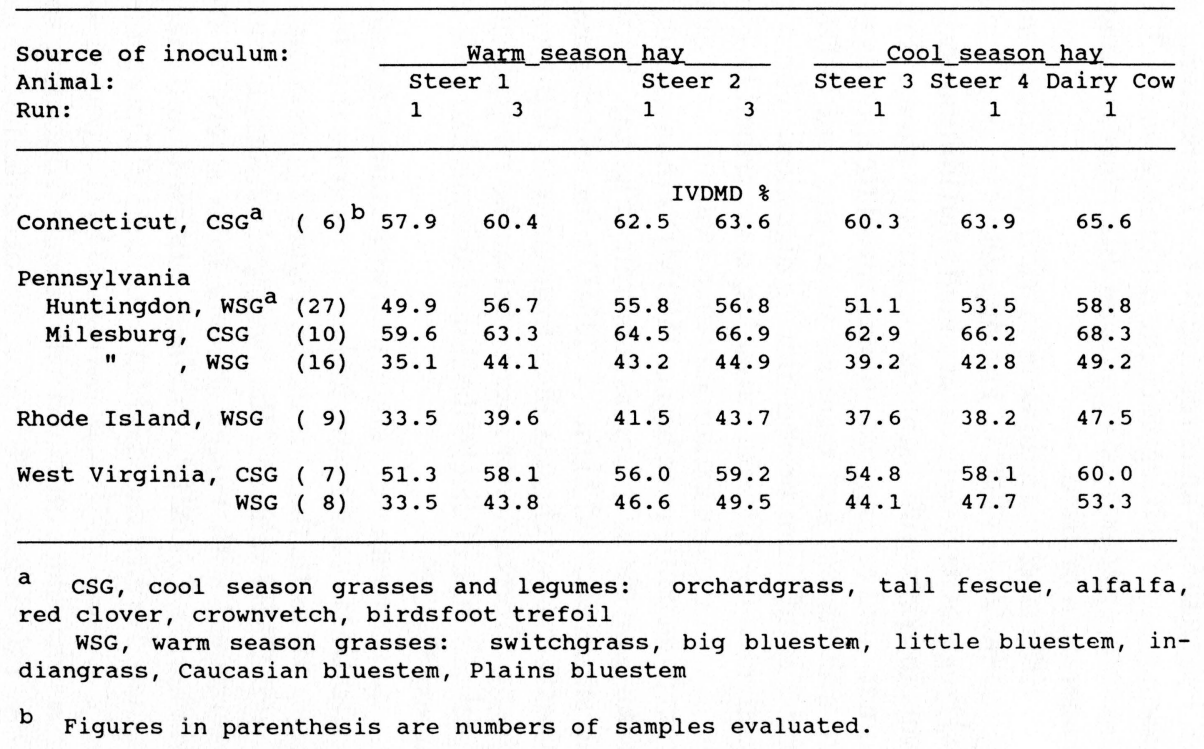


both cool season and warm season forages were obtained with rumen inocula from a dairy cow fed alfalfa hay. Warm season grass IVDMD values of samples harvested in West Virginia in 1979 and fermented using a sheep inoculum (warm season grass hay) were compared with IVDMD's of the same samples using a dairy cow inoculum (alfalfa hay) in Pennsylvania (J.A. Balasko, unpublished data). Higher IVDMD values were obtained using the West Virginia procedure, with an apparent forage class interaction; the mean difference in IVDMD of warm season grass samples using the West Virginia technique was +8.1 digestibility units relative to the Pennsylvania analysis; for cool season grasses and legumes the difference was +3.7 units. There do, therefore, appear to be significant differences among locations related to analytical method.

Effects of variations in in vitro procedure were further investigated by Vona (1982). The digestibilities of switchgrass and perennial ryegrass hays were determined at ad libitum and restricted feeding levels in trials with fistulated steers and sheep (Prigge et al., 1984). Rumen fluid taken from animals on all treatments was used to inoculate switchgrass and ryegrass substrates and IVDMD's were determined at different periods during digestion. The course of digestion, as affected by different variables, is described in Figure 1. Ryegrass was digested more extensively than switchgrass at all time periods. Inocula from cattle gave higher IVDMD's than inocula from sheep, particularly on the switchgrass substrate (Fig. 1a). Pooled data for cattle and sheep showed higher IVDMD's for switchgrass inoculated from animals fed switchgrass than from animals fed ryegrass, with no significant effect of donor animal diet on the ryegrass substrates (Fig. 1b). Level of intake of diet by the donor animals had little effect on IVDMD values (Fig. 1c).

In vitro data were compared with animal digestibility coefficients. In vivo $\mathrm{DMD}$ values were higher for ryegrass than for switchgrass, and higher for cattle than for sheep. Figure 2 gives comparative in vivo and in vitro DMD values of the two types of forage, with IVDMD values determined with rumen inocula from steers or from sheep. For switchgrass, IVDMD's obtained with cattle and sheep inocula underestimated in vivo cattle DMD by 6.1 and 10.2 percentage units, respectively. Deviations from in vivo DMD by sheep were +0.7 and -3.4 units for in vitro values obtained with inocula from cattle and sheep, respectively. For ryegrass substrates, use of cattle inocula gave in vitro values close to in vivo coefficients observed with both cattle and sheep. Use of rumen fluid from sheep underestimated cattle and sheep coefficients by 4.6 and 4.2 units, respectively. The results confirm previous findings of a greater deviation of in vitro from in vivo digestibility coef- 
Figure 1.Rates of in vitro dry matter disappearance of switchgrass (S) and perennial ryegrass (R) substrates as influenced by source of inoculum (sheep and cattle), type of diet (switchgrass or ryegrass) and level of intake (ad libitum or restricted) of donor animal. From Vona (1982).

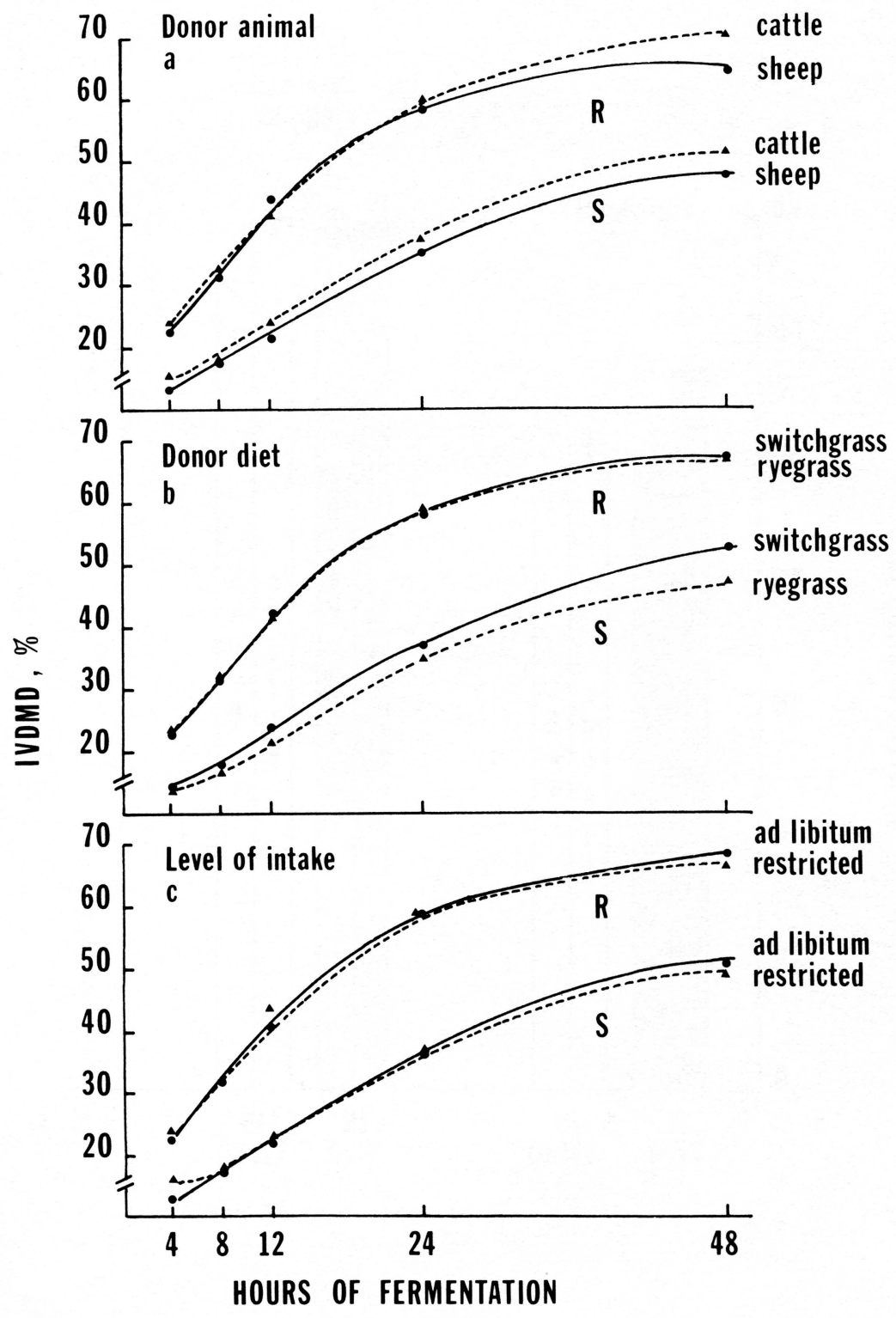


Figure 2. In vivo dry matter digestibility coefficients for switchgrass and ryegrass hays fed to sheep and cattle compared to in vitro coefficients with sheep or cattle as source of inoculum. From Vona (1982).

Perennial

ryegrass

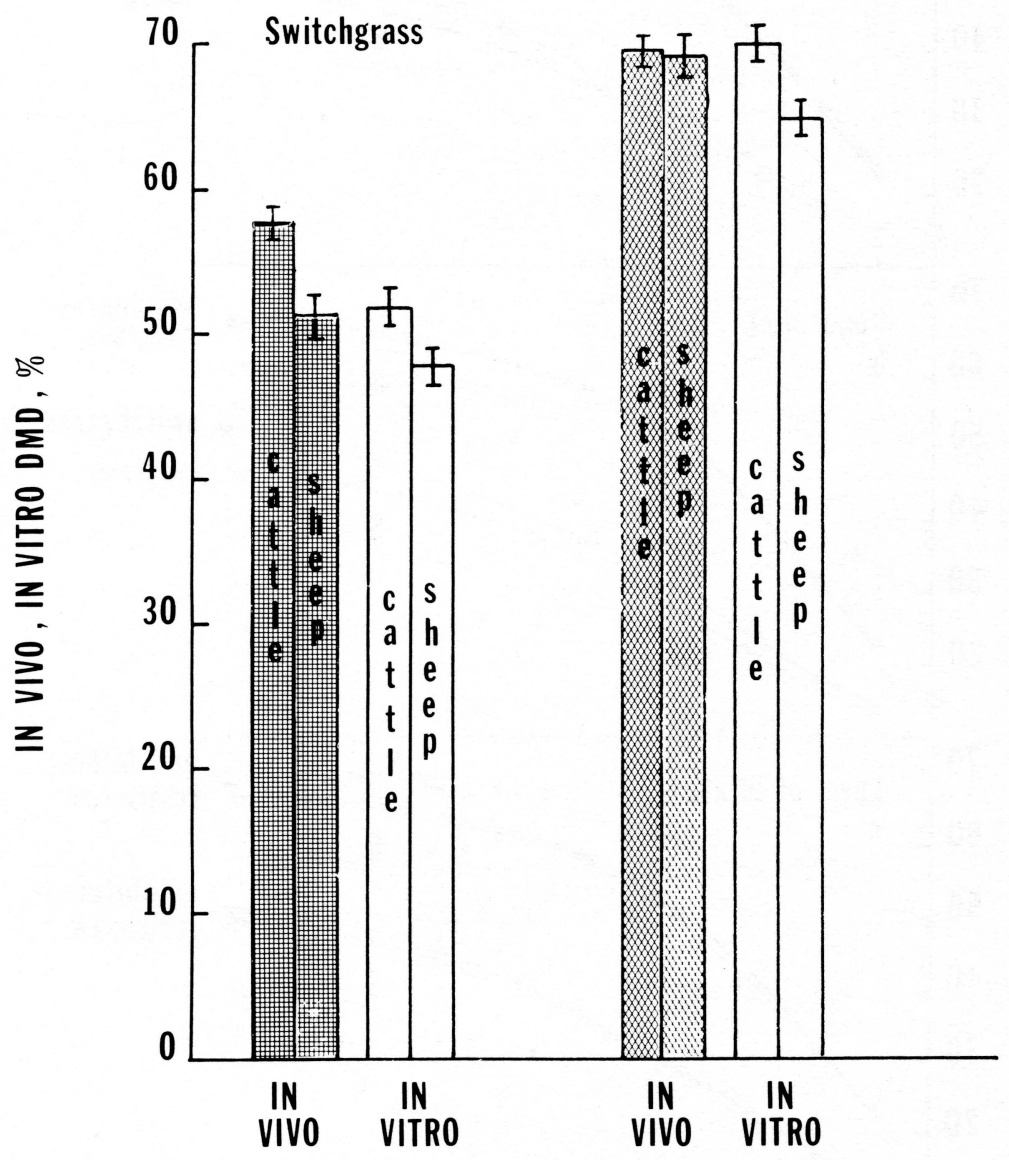


ficients with $\mathrm{C}_{4}$ than with $\mathrm{C}_{3}$ forages (Long, 1967; McLeod and Minson, 1969; Olubajo et al., 1974; Reid et al., 1973), but they do not account for the large differences observed by Griffin et al. (1980) with native warm season grasses.

\section{Nutritive Quality - Animal Trials}

It has generally been shown that the energy or dry matter digestibility of tropical forages is significantly lower than that of temperate species (Minson and McLeod, 1970; Minson, 1981a). Further, the digestibility of tropical grasses by cattle has been found to be higher than their digestibility by sheep (Playne, 1978; Ternouth et al., 1979; Poppi et al., 1981). However, few direct digestibility and intake measurements have been made with the native warm season grasses and no comparisons, to the authors' knowledge, with different animal species.

Griffin et al. (1980) fed Blackwell switchgrass and NY 1145 big bluestem harvested at three growth stages, with protein supplementation, to wether sheep in one trial and the same hays harvested at early heading, without protein, in another trial. In the first study, DMD values of the hays ranged from 67 to 74 percent and digestible energy, digestibility coefficients for NDF and ADF and intake of the warm season grasses were higher than for tall fescue harvested on the same dates. Dry matter digestibility declined 0.50 and 0.36 percentage units per day for big bluestem and switchgrass, respectively, with delay of harvest. In the second trial, without supplemental protein, DMD values ranged from 56 to 69 percent and digestibility and intake were lower than for tall fescue harvested at the same growth stage in spring. Intake was positively correlated with $\mathrm{DMD}(0.91), \mathrm{DE}(0.92)$ and crude protein concentration (0.95), and negatively with NDF (-0.84), ADF $(-0.89)$ and density $(-0.52)$ concentrations.

Vona et al. (1984), in West Virginia, conducted digestibility and intake trials with beef cows and sheep fed cultivars of switchgrass and big bluestem harvested at different growth stages in different locations (Kentucky, New Jersey, New York, Pennsylvania) in two years. As seen in Figure 3, both DMD and the rate of decline in DMD with advancing maturity of switchgrass differed between cattle and sheep. The rate of decline in DMD of switchgrass by sheep with delay in harvest was less than that for cattle and also lower than the rate reported for sheep by Griffin et al. (1980) in Pennsylvania. 
Figure 3. Rate of decline in dry matter digestibility of switchgrass hay by sheep and cattle with cutting date, compared to rates of decline of a warm season annual grass, cool season grass and a cool season legume.

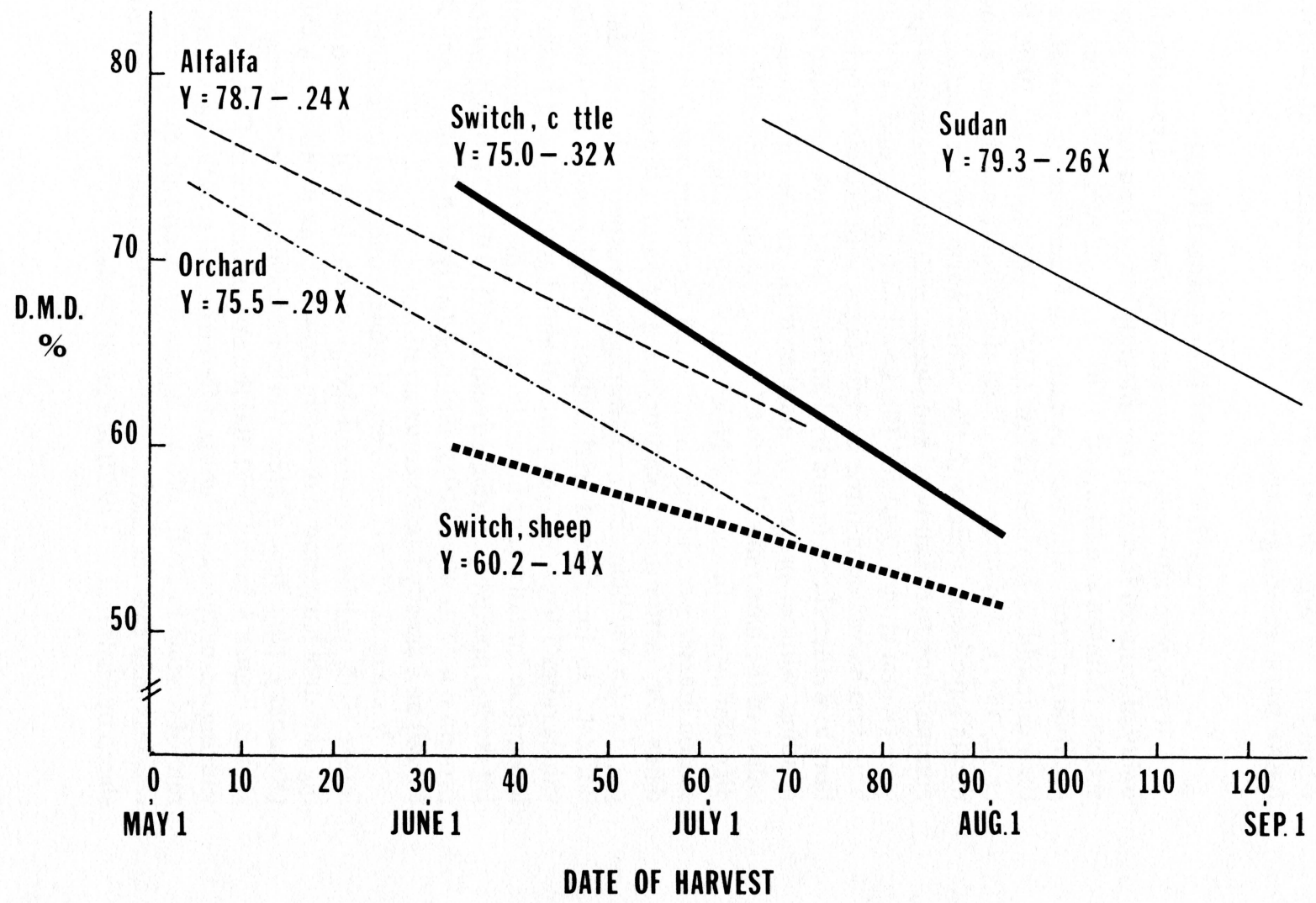


The linear regression equation calculated for cattle was not significantly different from linear regressions for orchardgrass (Dactylis glomerata L.), a legume (alfalfa) and a summer annual grass (sudangrass, Sorghum sudanense Stapf) fed to sheep in earlier trials in West Virginia.

Results of this study showed higher mean DMD and NDF digestibilities of warm season grass hays fed ad libitum by beef cows than by sheep ( 60.2 and 63.9 percent by cows vs. 53.2 and 55.2 percent by sheep), although protein digestibility did not differ between species. Level of intake was also higher by cows than by sheep (mean values of $92.3 \mathrm{vs} .67 .8 \mathrm{~g} / \mathrm{kg} \mathrm{BW}^{.75}$, respectively), although the differences in intake were not apparent when species were compared at the BW. ${ }^{9}$ power. While statistical analysis of location effects was tentative, there was little indication of differences in digestibility or intake associated with cultivar or with site at which the grasses were grown. Analyses of mineral balance in these trials (Figure 4) showed that cattle were in positive $\mathrm{Ca}, \mathrm{P}$ and $\mathrm{Mg}$ balance when hays were cut at the late vegetative growth stage, with slightly negative $\mathrm{Ca}$ and $\mathrm{P}$ retentions at later harvest dates, indicating a potential need for mineral supplementation. Sheep showed a negative $\mathrm{Ca}$ balance when fed hays at the late vegetative or early head cutting stages, but remained in positive $\mathrm{P}$ and $\mathrm{Mg}$ balance at all harvest times.

Subsequent feeding trials with cattle and sheep fed different cultivars of warm season grasses, or grasses fertilized with different $\mathrm{N}$ sources, have largely confirmed these observations (Reid et al., 1988). For a total of 78 warm season grass (switchgrass, big bluestem, flaccidgrass) hays fed to cattle, mean DMD and intake values were 60.0 percent and $89.8 \mathrm{~g} / \mathrm{kg} \mathrm{BW}^{77}$ respectively, compared with values of 54.5

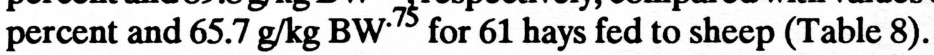

Results of these digestibility and intake studies with warm season grasses grown in the northeast United States may be compared with data for temperate and tropical grasses reviewed by Minson and McLeod (1970) in Australia. These workers developed a frequency distribution for DMD values of several hundred forages. This is shown in Figure 5 and compared with a frequency distribution for the DMD of cool season and warm season grasses fed to sheep and cattle in trials in West Virginia. It may be noted that the frequency distributions of the DMD's for cool and warm season grasses are more widely separated in the Australian than in the West Virginia population of forages. This may reflect the fact that data for temperate forages in the Australian review were, presumably, drawn largely from $\mathbf{N}$. European studies in which the digestibility of grasses is higher than that of herbage grown in latitudes farther south (Reid et al., 1959; Reid and 
Table 8.Mean Dry Matter Digestibility and Dry Matter and Neutral Detergent Fiber Intakes, with Standard Errors of the Means, for Sheep and Cattle Fed Different Classes of Forage. ${ }^{a}$

\begin{tabular}{|c|c|c|c|c|c|c|c|c|}
\hline \multirow{2}{*}{$\begin{array}{l}\text { Forage } \\
\text { class }\end{array}$} & \multicolumn{4}{|c|}{ Sheep } & \multicolumn{4}{|c|}{ Cattle } \\
\hline & $\mathrm{n}$ & DMD & DMI & NDFI & $\mathrm{n}$ & DMD & DMI & NDFI \\
\hline & & 8 & $---\mathrm{g} / \mathrm{kg}$ & $\mathrm{BW} \cdot 75 \ldots$ & & 8 & $---\mathrm{g} / \mathrm{kg}$ & $\mathrm{BW} \cdot 75$ \\
\hline Warm season grass & 61 & $54.5 \pm 0.7$ & $65.7 \pm 1.9$ & $48.6 \pm 1.1$ & 78 & $60.0 \pm 0.7$ & $89.8 \pm 2.0$ & $66.7 \pm 1.1$ \\
\hline Cool season grass & 184 & $65.5 \pm 0.4$ & $66.2 \pm 1.1$ & $40.8 \pm 0.6$ & 38 & $67.0 \pm 1.0$ & $89.5 \pm 2.9$ & $58.1 \pm 1.6$ \\
\hline Cool season legume & 183 & $62.1 \pm 0.4$ & $85.5 \pm 1.1$ & $43.7 \pm 0.6$ & 54 & $64.4 \pm 0.9$ & $99.7 \pm 2.4$ & $48.6 \pm 1.4$ \\
\hline
\end{tabular}

a From Reid et al. (1987a) 
Figure 4. Apparent retention of calcium, phosphorus and magnesium by cattle and sheep fed warm season grass hays harvested at different stages of maturity. From Vona (1982).

\section{CATtLe}

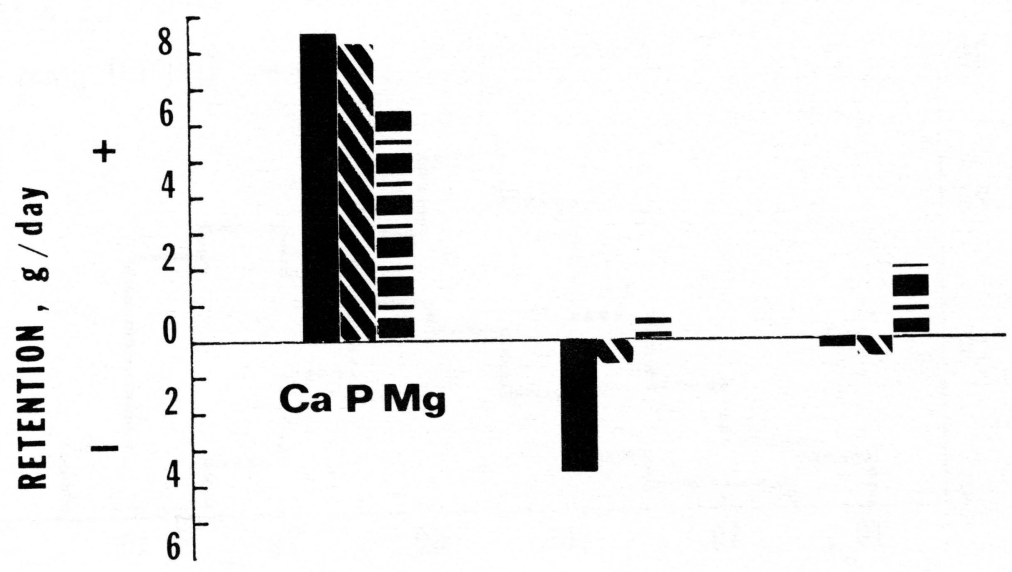

SHEEP

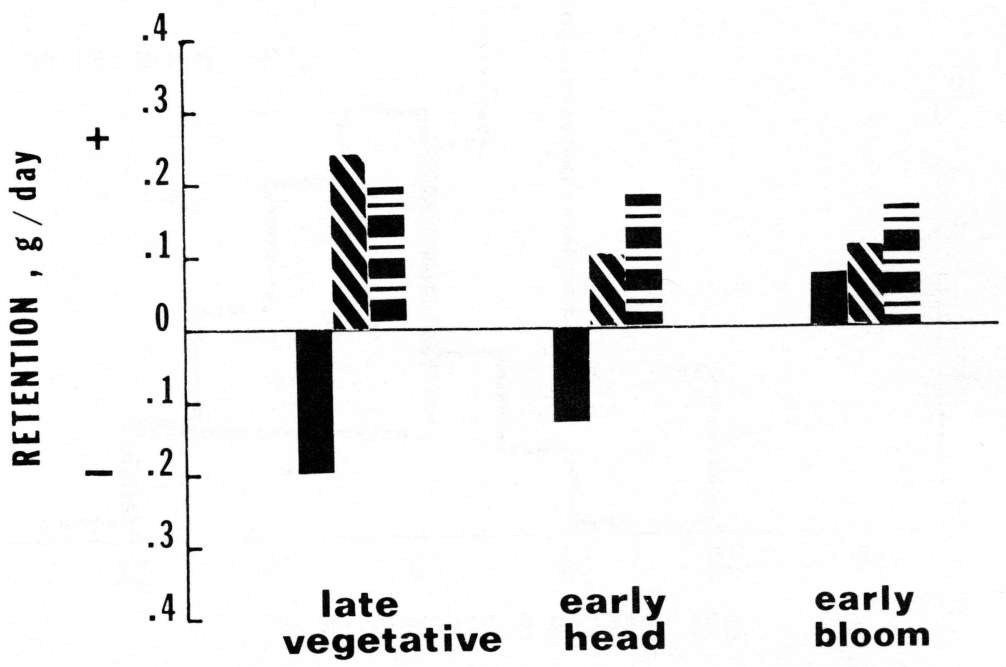


Figure 5. Frequency distributions of dry matter digestibilities of tropical and temperate grasses (Minson and McLeod, 1970) compared with distribution of values from warm season and cool season grasses in West Virginia feeding trials.

\section{AUSTRALIA}

- Temperate grass

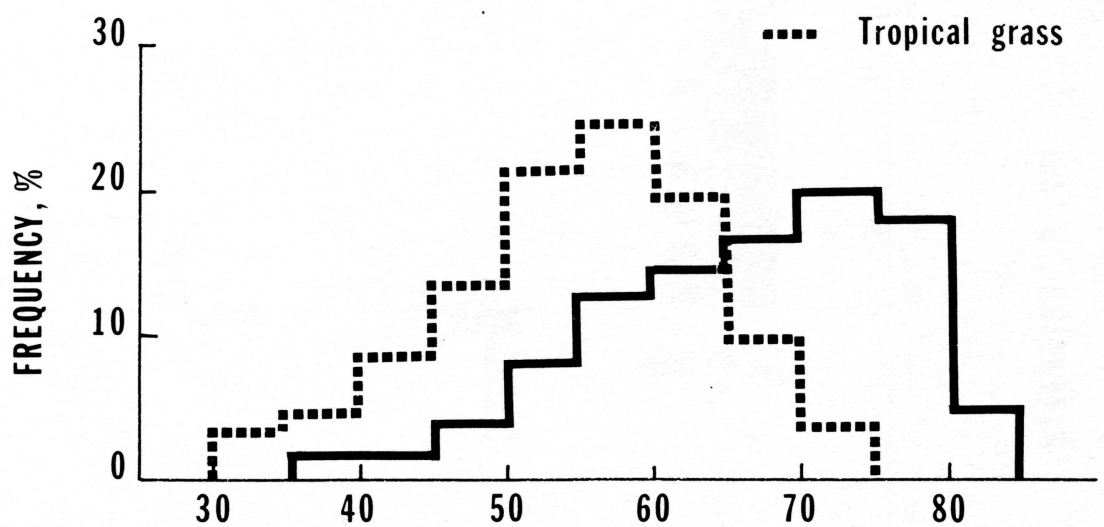

W. Va.

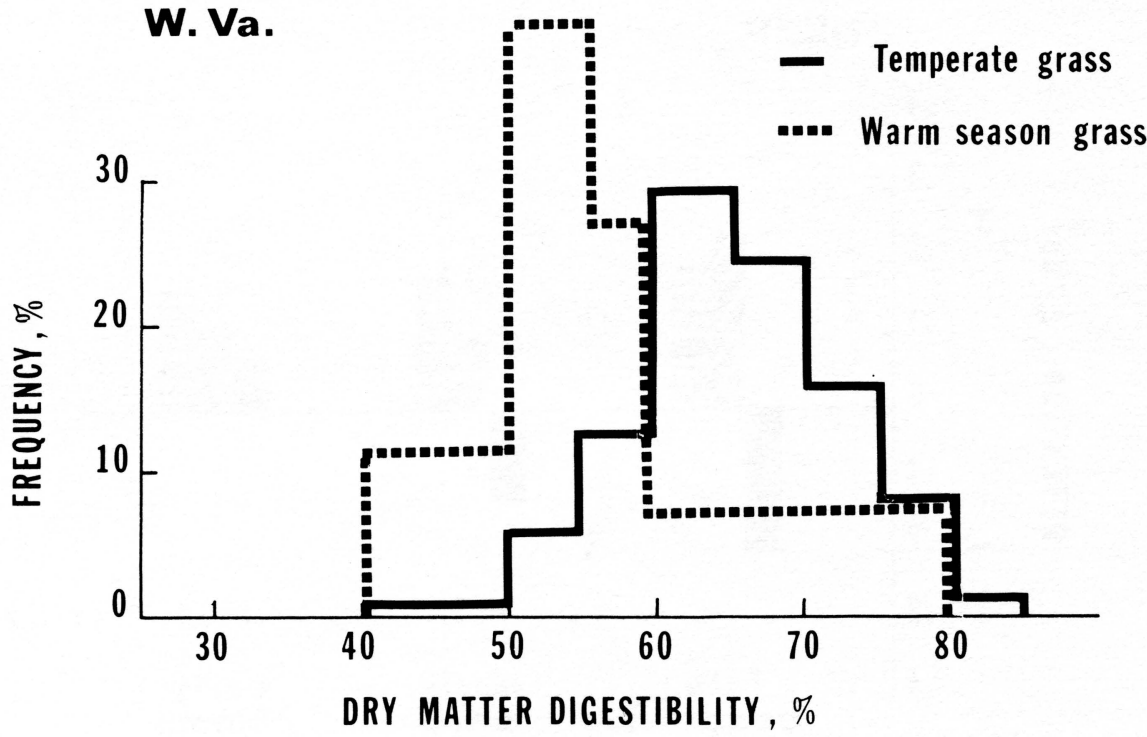


Jung, 1982). The mean difference in the DMD of populations of temperate and tropical grasses described by Minson and McLeod was approximately 13 digestibility units, compared with a difference of approximately 9 units in the West Virginia study.

What is of more interest is the frequency distribution of intake values observed for cool season and warm season grasses fed in West Virginia trials (Figure 6). The distribution curves essentially coincide. This finding was unexpected in light of the lower DMD values and markedly higher NDF and lower crude protein concentrations of the warm season grasses compared with temperate species, and has led to a reevaluation of factors controlling the intake of different types of forages by ruminant animals. It also provides at least a partial explanation for the frequent observation of good rates of gain in animals grazing warm season grasses. This will be discussed further in the section on Grazing Studies.

Table 8 summarizes data on the DMD and intake of cool season grasses, cool season legumes and warm season grasses fed to cattle and sheep (Reid et al., 1988). For sheep, the mean DMD of 61 samples of warm season grass hays was 54.5 percent, compared with a mean value of 65.5 percent for a group of $184 \mathrm{cool}$ season grasses and of 62.1 percent for 183 legumes. For cattle, mean DMD's were 60.0, 67.0 and 64.4 percent, respectively. However, for both sheep and cattle, intake levels of the warm season grasses were the same as for the cool season grasses, with the highest intakes recorded for the legumes.

It is suggested that cattle, and sheep to a lesser extent, attain this relatively high dry matter intake of warm season grasses, of lower digestibility and higher fiber content, by increasing fiber intake and gut fill. Calculated NDF intakes (Table 8) by both sheep and cattle were highest for the warm season grasses and increased with increasing NDF concentrations of the forage. This finding is not in accord with current concepts of intake control in ruminants fed forage diets (Van Soest, 1982) and will require further study of retention times, turnover rates and rates of particle size reduction in animals maintained on different classes of forage. Current trials in Pennsylvania and West Virginia are examining these factors.

Analysis of relationships between digestibility and intake of warm season grasses and their chemical composition indicates that different regressions may be required for the prediction of nutritive quality of $\mathrm{C}_{4}$ forages than are applicable to temperate forages (Reid et al., 1988). Also, different regressions between quality factors (digestibility, intake) and composition may apply to cattle and sheep. A summary of significant regressions between DMD, intake and ADF and NDF concentrations of populations of warm season grasses and cool season 
Figure 6. Frequency distributions of levels of intake of warm season and cool season grasses in West Virginia trials.

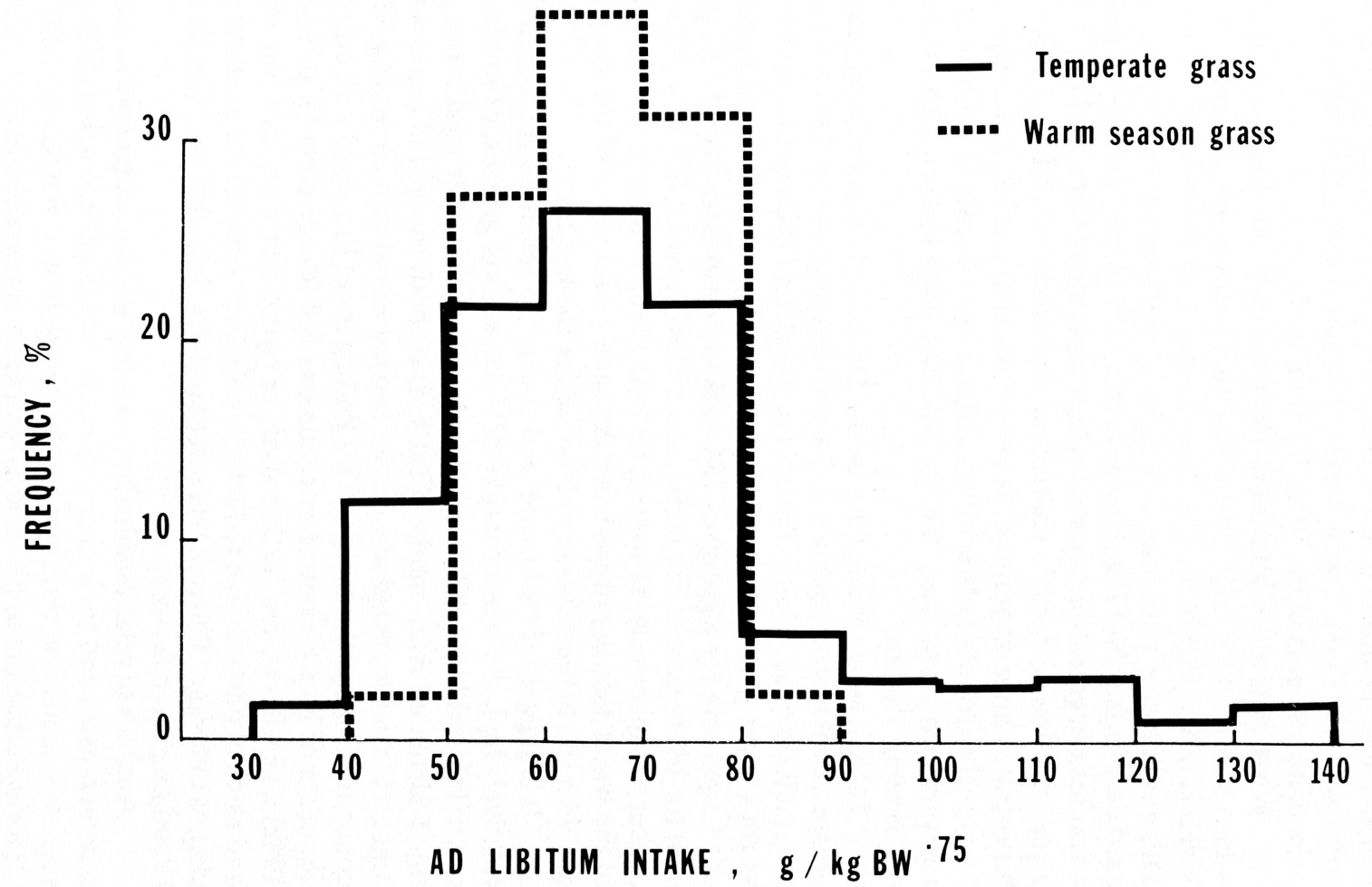


grasses and legumes fed to sheep and cattle in West Virginia trials is given in Table 9. It will be seen that, in most cases, regressions were linear. The relatively high standard errors of estimate (sy.x) and low $R^{2}$ values of the regressions indicates, however, that the detergent fiber fractions would have only limited value as predictors of digestibility and intake of the warm season grasses or, indeed, any class of forage.

The apparent need for different regressions to predict nutritive indices of different classes of forage from their fiber fractions is, again, not in agreement with Van Soest (1982) theory of forage evaluation and suggests that further detailed study of the chemical composition and metabolism of cell wall components in $\mathrm{C}_{3}$ and $\mathrm{C}_{4}$ forages is desirable.

\section{Grazing Studies}

Earlier grazing trials at the Western Pennsylvania Forage Beef Farm (Jung et al., 1978) with warm season grass stands on low fertility soils ( $\mathrm{pH}$ 5.3, low $\mathrm{P}$, no $\mathrm{N}$ ) gave cow grazing days of 215 per hectare, representing about 60 percent of total annual cow grazing days. Carrying capacity varied widely between grasses and the authors concluded that 325 cow grazing days per hectare could be expected from the more productive stands such as Blackwell switchgrass. Behavioral observations indicated that little bluestem was most highly preferred and indiangrass least. Cattle grazed the lower part of the bluestem plant but tended to avoid the lower sections of switchgrass. It was found that close grazing of grasses in midsummer generally resulted in loss of stand, and animal management was adjusted to leave a $20 \mathrm{~cm}$ stubble on switchgrass.

Fairbairn et al. (1985) reported responses with a cow-calf herd grazing switchgrass in southeast Pennsylvania. Animals were initially grazed on cool season grass pastures, then rotationally grazed on switchgrass for 10 day periods at a stocking rate of approximately 18.7 animal units (AU) per hectare. Grazing was begun when switchgrass reached a height of $120 \mathrm{~cm}$ and cattle were moved at a stubble height of $30 \mathrm{~cm}$. After 30 days of grazing, animals were alternated between cool season pastures and warm season grass regrowth until November. During the first grazing period, cows gained an average $0.68 \mathrm{~kg} /$ day and calves an average $0.96 \mathrm{~kg} /$ day.

In southwest Pennsylvania, Jung et al. (1985) evaluated the use of mixed warm season grass-cool season grass and legume pastures with beef cows and calves. Pastures were heavily grazed in mid-May to utilize the cool season species and reduce competition with growth of the warm season grasses in June. Plots were grazed three times per year 


\section{Table 9. Significant Regression Equations Between Dry Matter Digestibility, Intake and Fiber Components for Forage Classes Fed to Sheep and Cattle. ${ }^{a}$}

\begin{tabular}{|c|c|c|c|c|}
\hline Regression & class ${ }^{b}$ & Regression equation & sy.xc & R2 \\
\hline \multicolumn{5}{|l|}{ Dry $n$} \\
\hline \multirow[t]{3}{*}{ Sheep } & CSG & $\mathrm{Y}=100.3-0.97 \mathrm{X}$ & 5.5 & .38 \\
\hline & CSL & $\mathrm{Y}=74.3-0.35 \mathrm{X}$ & 4.5 & .15 \\
\hline & WSG & $87.7-0.78 x$ & 3.4 & .45 \\
\hline Cattle & WSG & $\mathrm{Y}=98.5-0.90 \mathrm{X}$ & 6.8 & .23 \\
\hline
\end{tabular}

Dry matter digestibility on neutral detergent fiber $(\%)$

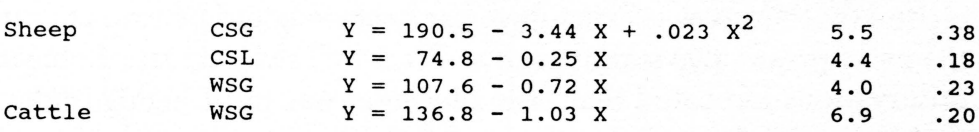

Dry matter intake on neutral detergent fiber ( $\%$ )

$\begin{array}{llllr}\text { Sheep } & \text { CSG } & Y=103.6-0.60 \mathrm{X} & 16.3 & .05 \\ & \text { CSL } & \mathrm{Y}=140.3-1.05 \mathrm{X} & 12.2 & .35 \\ \text { Cattle } & \text { WSG } & \mathrm{Y}=187.0-1.63 \mathrm{X} & 9.6 & .22 \\ & \text { CSG } & \mathrm{Y}=169.3-1.22 \mathrm{X} & 9.9 & .29 \\ & \text { CSL } & \mathrm{Y}=153.5-1.08 \mathrm{X} & 20.2 & .18 \\ & \text { WSG } & \mathrm{Y}=282.3-2.58 \mathrm{X} & 14.6 & .26\end{array}$

\footnotetext{
a From Reid et al. (1987a)

b CSG, cool season grass; CSL, cool season legume; WSG, warm season grass

c Standard error of estimate
} 
and animals were removed from switchgrass and big bluestem pastures at a stubble height of $20 \mathrm{~cm}$. A stocking density of $33 \mathrm{AU}$ per hectare in summer was used. It was calculated that, for the whole growing season, the mixed warm and cool season grass pastures provided four times as many AU grazing days per hectare as adjacent cool season grass and legume pastures (Jung, 1986).

In West Virginia, alternative grazing management systems were compared on a droughty upland area between 1981 and 1984 (Reid and Jung, 1985; Jung et al., 1987). During the first two years, yearling cattle grazed permanent bluegrass-white clover pastures in spring and were then set stocked on individual warm season grass pastures (switchgrass, big bluestem, indiangrass, Caucasian bluestem, Plains bluestem) at a stocking density of approximately $4 \mathrm{AU}$ per hectare until fall, when they were returned to the cool season pastures. Grazing was begun at a plant height of 60 to $75 \mathrm{~cm}$ and terminated at 15 to $20 \mathrm{~cm}$.

Under this system, ADG's in the first 3 to 4 weeks ranged from $0.86 \mathrm{~kg} /$ day for Plains bluestem to $1.14 \mathrm{~kg} /$ day for switchgrass, with calculated intakes of 8.3 to $10.9 \mathrm{~kg}$ DM per day. Gains and intake then declined. In vitro DMD's on whole plant herbage were in the range of 60 to 65 percent in late June, decreasing to 45 to 50 percent in August. This system permitted considerable wastage of herbage and the management system was modified in the next two years to a rotational grazing system on switchgrass, big bluestem and Caucasian bluestem, with higher stocking rates (10 AU per hectare), and initiation of grazing on switchgrass at a height of 35 to $40 \mathrm{~cm}$. Pastures were then defoliated in periods of 10 to 14 days. Under this integrated system, pastures were more uniformly grazed, digestibility of the herbage was increased and ADG's of cattle were maintained. Seasonal ADG's averaged $0.57 \mathrm{~kg} /$ day and liveweight gains per hectare averaged $148 \mathrm{~kg}$.

This system was compared with two others, one on permanent bluegrass-clover pastures grazed at low set stocking rates from spring to fall and the other on tall fescue or bluegrass-orchardgrass pastures fertilized with $\mathrm{N}$ and grazed at varying stocking rates. The "tradition$\mathrm{al}$ " system gave mean ADG's of $0.64 \mathrm{~kg} /$ day but a low liveweight gain $(60 \mathrm{~kg})$ per hectare. The system with fertilized cool season grasses gave mean ADG's of $0.30 \mathrm{~kg} /$ day and liveweight gains of $147 \mathrm{~kg}$ per hectare.

Behavioral studies were conducted on grazing cattle on the different management systems using the fecal carbon isotope technique (Jones, 1981), following the observation of incursion of cool season grasses and legumes into the warm season grass pastures. In the first phase of the study, cattle in early summer selected $C_{3}$ and $C_{4}$ species in proportion to the percentage of ground cover supplied by the two types of herbage. In one year, animals grazing regrowth warm season 
grasses in early fall showed a definite preference for volunteer clover. During the second phase, on rotational management at higher stocking density, cattle grazing switchgrass and big bluestem pastures selected a higher percentage of $\mathrm{C}_{4}$ species in their diet than when managed on a set stocking basis at lower stocking rates.

These grazing studies confirm the results of those conducted in the North Central and Great Plains states which show that the warm season grasses can, when managed effectively, maintain good rates of gain in grazing cattle and, when used in conjunction with cool season permanent pastures, increase the level of animal output on marginal land. Some reasons for the responses of ruminant animals to the warm season grasses have been examined. Many other factors which may influence their nutritional value and utilization remain to be tested. 


\section{Conclusions}

The research conducted in this regional project has, it is hoped, served to clarify some of the questions raised in the Introduction. The native warm season grasses grown in different areas of the Northeast have many of the quality and compositional characteristics of typical tropical forages - high concentrations of cell wall fractions, ${ }^{13} \mathrm{C}:{ }^{12} \mathrm{C}$ ratios, low levels of $\mathrm{N}$ and certain elements, relatively low IVDMD and in vivo DMD values. Yet it would appear - from a comparative analysis of Australian data with results of this regional project - that where $C_{3}$ and $\mathrm{C}_{4}$ forages are grown in similar temperate conditions, differences in nutritive quality are not as great as might be expected.

One of the confounding factors affecting interpretation of research with warm season grasses is that much reliance has been placed on the in vitro technique as an index of digestibility. Most such data show low IVDMD values and these have been taken as indicative of poor feeding quality. Results of the present study confirm that there appear to be real differences between in vivo-in vitro digestibility relationships obtained with $\mathrm{C}_{3}$ and $\mathrm{C}_{4}$ forages. However, no immediate cause of the major discrepancies between in vivo and in vitro digestibility coefficients obtained in the Pennsylvania reports can be defined. It was apparent that in vitro techniques using different sources of inoculum in Pennsylvania and West Virginia gave different results, and further testing and standardization of procedures is obviously required if this method of evaluating forages is to be used routinely. Possibly longer periods of incubation than are currently employed may be required to provide better measures of the digestibility of warm season grasses. Comparative studies of warm season grass digestion with rumen fluid and cellulase preparations may explain the discrepancies.

When relationships between animal measurements of nutritive quality and chemical components, particularly the detergent fiber fractions, were examined it was evident that regression equations developed for the prediction of digestibility and intake of temperate grasses and legumes differed from those for warm season grasses, and also differed between sheep and cattle. This was an unexpected finding and, in one sense, represents a retrograde step in forage evaluation procedures. One of the limitations ascribed to the proximate analysis system was the fact that relationships between digestibility and chemical composition were significantly influenced by type of forage, e.g. grasses vs legumes. Results of the present study, if confirmed, would indicate that application of the Van Soest system of analysis in prediction of digestiblity and (or) intake has not solved the problem. It was 
also clear that use of single component regressions for prediction of digestibility or intake from detergent fiber analysis did not provide an acceptable degree of accuracy for any class of forage, an observation which has been made by many other workers.

Mineral analysis of the warm season grasses, and relationships between IVDMD and $N$ and $P$ concentrations, suggest that a low uptake of certain elements may potentially limit animal response. Much of the evidence is admittedly circumstantial but, from results of trials reported in many areas of the world, mean concentrations of 7.6 percent crude protein, 0.17 percent $P$ and 0.14 percent $S$ in the warm season grasses analyzed might well be expected to reduce digestibility, intake and animal growth or lactation. While the main objective of this regional project was to identify grasses and legumes which would establish and grow well on soils of limiting fertility, one consequence with the warm season grasses appears to be a limited uptake of certain elements essential for optimal animal nutrition. Trials have been initiated to investigate the effects of certain elements $(\mathrm{N}, \mathrm{S})$ on nutritive quality of the warm season grasses and further research on this problem seems warranted. If significant effects are demonstrated, some form of mineral supplementation of animal diets or appropriate fertilizer treatment may provide an effective control.

The feeding trials conducted have provided much-needed data on the digestibility and intake of warm season grasses by cattle and sheep and have opened new areas of investigation on basic questions of intake regulation and digestive utilization of forage diets by ruminant animals. The demonstration of unexpectedly high levels of dry matter intake, particularly by cattle, of grasses of low digestibility and high fiber concentration indicates that accepted theories of intake regulation via gut distention factors may require modification. Cattle appear to utilize the warm season grasses more efficiently than do sheep and this offers some direct guidelines in terms of decisions involving use of the grasses in livestock management.

The research on nutritive quality of the warm season grasses in feeding trials provides at least a partial explanation of one of the unexplained features of grazing studies in different regions - the fact that cattle show much better rates of gain than would be expected from various forms of laboratory evaluation of the forage. A high intake, combined with selective grazing of leaf material of higher digestibility and nutrient content, would account for the good performance of grazing animals reported in numerous studies. It also seems possible that the relatively high gains of cattle reported in grazing trials may result in part from higher levels of gut fill rather than from increases in tissue gain. Slaughter experiments are needed to answer this question. 
While only a limited number of controlled grazing trials with warm season grasses were performed within this regional project, the results obtained - together with an increasing number of trials on private farms - show that use of warm season grasses in integrated grazing management systems on marginal land areas can significantly increase the level of livestock production. Trials in Pennsylvania and West Virginia have demonstrated key requirements in such a management system - early spring grazing of permanent grass - clover pastures, intensive defoliation of cool season species on the warm season grass pastures in May to reduce competition, followed by rotational grazing on the warm season grasses at high stocking pressure and, finally, return of animals to permanent pastures in the fall. In West Virginia, this system was found to support reasonable season-long ADG's in yearling cattle and to increase livestock output per unit of land when compared to either traditional or improved systems of grazing management based on cool season pastures alone.

Results of these studies on nutritive quality of the warm season grasses need to be considered, as in any forage system, with data on establishment, yield and persistence of the grasses under varying conditions of climate, soils, fertilization and grazing management. These factors will be discussed in individual publications of stations contributing to the NE-114 Regional Project. 
[Blank Page in Original Bulletin] 


\section{Literature Cited}

Abrams, S.M., H. Hartadi, C.M. Chaves, J.E. Moore and W.R. Ocumpaugh. 1983. Relationship of forage-evaluation techniques to the intake and digestibility of tropical grasses. Proc. XIV Inter. Grassl. Congr. pp. 508-511. Lexington, KY.

Akin, D.E. 1982. Microbial breakdown of feed in the digestive tract. In: J.B. Hacker (ed.). Nutritional Limits to Animal Production from Pastures. pp. 201-223. Commonwealth Agric. Bureaux, Farnham Royal, UK.

Akin, D.E. 1986. Interaction of ruminal bacteria and fungi with southern forages. J. Anim. Sci. 63:962-977.

Anderson, B. and A.G. Matches. 1983. Forage yield, quality, and persistence of switchgrass and Caucasian bluestem. Agron. J. 75:119-123.

AOAC. 1980. Official Methods of Analysis. 13th ed. Washington, DC : Association of Official Analytical Chemists.

Arnold, G.W. 1981. Grazing behavior. In: F.H.W. Morley (ed.). Grazing Animals. pp. 79-104. Elsevier Sci. Publ. Co., Amsterdam-Oxford-New York.

Bailey, R.W. 1973. Structural carbohydrates. In: G.W. Butler and R.W. Bailey (eds.). Chemistry and Biochemistry of Herbage. Vol. 1. pp. 157-211. Academic Press, London, New York.

Balasko, J.A. and Dale Smith. 1971. Influence of temperature and nitrogen fertilization on the growth and composition of switchgrass (Panicum vingatum L.) and timothy (Phleum pratense L.) at anthesis. Agron. J. 63:853-857.

Balasko, J.A., D.M. Burner and W.V. Thayne. 1984. Yield and quality of switchgrass grown without soil amendments. Agron. J. 76:204-208.

Barnes, R.F. 1973. Laboratory methods of evaluating feeding value of herbage. In: G.W. Butler and R.W. Bailey (eds.). Chemistry and Biochemistry of Herbage. Vol. 3. pp. 179-214. Academic Press, London, New York. 
Bredon, R.M., K.W. Harker and B. Marshall. 1963. The nutritive value of grasses grown in Uganda when fed to Zebu cattle. 1 . The relation between the percentage of crude protein and other nutrients. J. Agric. Sci. (Camb). 61:101-104.

Bredon, R.M. and C.R. Horrell. 1961. The chemical composition and nutritive value of some common grasses in Uganda. I. General pattern of behavior of grasses. Trop. Agr. (Trinidad) 38:297304.

Bughrara, S.S. and D.A. Sleper. 1986. Digestion of several temperate forage species by a prepared cellulase solution. Agron. J. 78:94-98.

Burns, J.C., R.D. Mochrie and D.H. Timothy. 1984. Steer performance from two perennial Pennisetum species, switchgrass, and a fescue - 'Coastal' bermudagrass system. Agron. J. 76:795-800.

Butterworth, M.H. 1967. The digestibility of tropical grasses. Nutr. Abst. Rev. 37:349-368.

Chacon, E.A. and T.H. Stobbs. 1976. Influence of progressive defoliation of a grass sward on the eating behavior of cattle. Aust. J. Agric. Res. 27:709-727.

Chacon, E.A., T.H. Stobbs and M.D. Dale. 1978. Influence of sward characteristics on grazing behavior and growth of Hereford steers grazing tropical grass pastures. Aust. J. Agric. Res. 29:89-102.

Conard, E.C. and D.C. Clanton. 1963. Cool-season, warm-season pastures needed. Nebraska Agric. Exp. Sta. Beef Cattle Progess Rep. pp. 11-13.

Deinum, B. 1983. Chemical composition and nutritive value of herbage in relation to climate. Proc. 10th Meeting Eur. Grassl. Fed., Norway. pp. 338-350.

Deinum, B. and J.G. Dirven. 1974. A model for the description of the effects of different environmental factors on the nutritive value of forage. Proc. XII Inter. Grassl. Cong. pp. 338-346. Moscow, U.S.S.R.

Dwyer, D. and W. Elder. 1964. Grazing comparison of Woodward sand bluestem and Caddo switchgrass in Oklahoma. Oklahoma Agric. Exp. Sta. Bull. B-628. 
Edwards, G. and D.A. Walker. 1983. $\mathrm{C}_{3}, \mathrm{C}_{4}$ : Mechanisms, and Cellular and Environmental Regulation of Photosynthesis. Univ. of California Press, Los Angeles.

Fairbairn, C.A., G.A. Jung and L.D. Hoffman. 1985. Use of switchgrass to extend summer grazing in S.E. Pennsylvania. NE Branch, Am. Soc. Agron. Abst. p. 9.

Fisher, D.S., K.R. Pond and J.C. Burns. 1987. An interdisciplinary approach to pasture-animal interface research. In: F.P. Horn, J. Hodgson, J.J. Mott and R.W. Brougham (eds.). Grazing Lands Research at the Plant-Animal Interface. pp. 3-20. Winrock International, Morrilton, AR.

Fleming, G.A. 1973. Mineral composition of herbage. In: G.W. Butler and R.W. Bailey (eds.). Chemistry and Biochemistry of Herbage. Vol. 1. pp. 529-566. Academic Press, London, New York.

Forbes, T.D.A. and S.W. Coleman. 1987. Herbage intake and ingestive behavior of grazing cattle as influenced by variation in sward characteristics. In: F.P. Horn, J. Hodgson, J.J. Mott and R.W. Brougham (eds.). Grazing Lands Research at the Plant-Animal Interface. pp. 141-152. Winrock International, Morrilton, AR.

Ford, C.W., I.M. Morrison and J.R. Wilson. 1979. Temperature effects on lignin, hemicellulose and cellulose in tropical grasses. Aust. J. Agric. Res. 30:621-633.

Friedrich, J.W., Dale Smith and L.E. Schrader. 1977. Herbage yield and chemical composition of switchgrass as affected by N, S and $\mathrm{K}$ fertilization. Agron. J. 69:30-33.

Goering, H.K. and P.J. Van Soest. 1970. Forage fiber analyses. U.S. Dept. Agric., Agric. Handbook 379.

Goodrich, R.D., T.S. Kahlon, D.E. Pamp and D.P. Cooper. 1978. Sulfur in ruminant nutrition. National Feed Ingredients Assoc., West Des Moines, IA. pp. 35-40.

Griffin, J.L. and G.A.Jung. 1981. Yield and forage quality of Panicum virgatum. Proc. XIV Inter. Grassl. Cong. pp. 491-494. Lexington, $\mathrm{KY}$.

Griffin, J.L. and G.A. Jung. 1983. Leaf and stem forage quality of big bluestem and switchgrass. Agron. J. 75:723-726. 
Griffin, J.L., P.J. Wangsness and G.A. Jung. 1980. Forage quality evaluation of two warm-season range grasses using laboratory and animal measurements. Agron. J. 72:951-956.

Hodgson, J., J.F. Rodriguez Capriles and J.S. Fenlon. 1977. The influence of sward characteristics on the herbage intake of grazing calves. J. Agric. Sci. (Camb.) 89:743-750.

Horn, F.P. and W. Jackson. 1979. Digestibility of five "Old world bluestem" hays. Oklahoma Agric. Exp. Sta. Anim. Sci. Res. Report.

Johnson, W.L., J. Guerrero and D. Pezo. 1973. Cell-wall constituents and in vitro digestibility of Napier grass (Pennisetum purpureum). J. Anim. Sci. 37:1255-1261.

Jones, C.A. 1985. $\mathrm{C}_{4}$ Grasses and Cereals. Growth, Development and Stress Response. John Wiley and Sons, New York. p. 419.

Jones, R.J. 1981. The use of natural carbon isotope ratios in studies with grazing animals. In: J.L. Wheeler and R.D. Mochrie (eds.). Forage Evaluation : Concepts and Techniques. pp. 277- 286. AFGC, CSIRO, Griffin Press Ltd., Netley, S. Australia.

Jung, G.A. 1986. How warm-season grasses perform in the Northeast. In: Warm Season Grasses : Balancing Forage Programs in the Northeast and Southern Corn Belt. pp. 19-22. Soil Cons. Soc. Am., Ankeny, IA.

Jung, G.A., J.L. Griffin, R.E. Kocher, J.A. Shaffer and C.F. Gross. 1985. Performance of switchgrass and bluestem cultivars mixed with cool-season species. Agron. J. 77:846-850.

Jung, G.A., C.F. Gross, R.E. Kocher, L.A. Burdette and W.C. Sharp. 1978. Warm-season range grasses extend beef cattle forage. Sci. Agric. 25(2):6.

Jung, G.A., R.L. Reid, L.C. Vona and L.P. Stevens. 1987. Grazing systems, herbage quality, and animal behavior on warm- season and cool-season grass pastures on hill country in the northeastern United States. In: F.P. Horn, J. Hodgson, J.J. Mott and R.W. Brougham (eds.). Grazing Lands Research at the Plant-Animal Interface. pp. 45-63. Winrock International, Morrilton, AR. 
Jung, G.A., J.A. Shaffer and W.L. Stout. 1987. Growth and forage quality of switchgrass and big bluestem grown on a strongly acid soil. Agron. J. (in press).

Kaiser, C.J., G.F. Cmarik and D.B. Faulkner. 1986. How warmseason grasses perform in the southern Corn Belt. In: Warm Season Grasses : Balancing Forage Programs in the Northeast and Southern Corn Belt. pp. 23-26. Soil Cons. Soc. Am., Ankeny, IA.

Kayongo-Male, H., J.W. Thomas and D.E. Ullrey. 1972. Laboratory evaluation of Puerto Rican grasses. J. Anim. Sci. 35:231-236

Koshi, P.T., J. Stubbendieck, H.V. Eck and W.G. McCully. 1982. Switchgrasses: forage yield, forage quality and water-use efficiency. J. Range Manage. 35:623-627.

Krueger, C.R. and D.C. Curtis. 1979. Evaluation of big bluestem, sideoats grama, and switchgrass pastures with yearling steers. Agron. J. 71:480-482.

Long, M.I.E. 1967. Investigations on the in vitro digestibility techniques used under East African conditions. East Afr. Agric. J. 33:166-169.

Ludlow, M.M., T.H. Stobbs, R. Davis and D.A. Charles-Edwards. 1982. Effect of sward structure of two tropical grasses with contrasting canopies on light distribution, net photosynthesis and size of bite harvested by grazing cattle. Aust. J. Agric. Res. 33:187-201.

Marten, G.C. 1981. Chemical, in vitro and nylon bag procedures for evaluating forages in the USA. In: J.L. Wheeler and R.D. Mochrie (eds.). Forage Evaluation : Concepts and Techniques. pp. 39-56. AFGC, CSIRO. Griffin Press Ltd., Netley, S. Australia.

Matches, A.G., S. Bell, M. Mitchell and F.A. Martz. 1977. Pasture systems for season-long grazing. Res. Rep. Coop. Univ. Missouri, Columbia, Southwest Missouri Center.

Mayland, H.F. and D.L. Grunes. 1979. Soil-climate-plant relationships in the etiology of grass tetany. In: D.L. Grunes (ed.). Grass Tetany. ASA Special Publ. No. 35. pp. 123-175. Am. Soc. Agron., Crop Sci. Soc. Am., Soil Sci. Soc. Am. Madison, WI. 
McLeod, M.N. and D.J. Minson. 1969. Sources of variation in the in vitro digestibility of tropical grasses. J. Brit. Grassl. Soc. 24:244-249.

Minson, D.J. 1981a. Nutritional differences between tropical and temperate pastures. In: F.H.W. Morley (ed.). Grazing Animals. pp. 143-158. Elsevier Sci. Publ. Co., AmsterdamOxford-New York.

Minson, D.J. 1981b. An Australian view of laboratory techniques for forage evaluation. In: J.L. Wheeler and R.D. Mochrie (eds.). Forage Evaluation: Concepts and Techniques. pp. 57-74. AFGC, CSIRO. Griffin Press, Ltd., Netley, S.Australia.

Minson, D.J. 1982. Effects of chemical and physical composition of herbage eaten upon intake. In: J.B. Hacker (ed.). Nutritional Limits to Animal Production from Pastures. pp. 167- 182. Commonwealth Agric. Bureaux, Farnham Royal, UK.

Minson, D.J. and M.N. McLeod. 1970. The digestibility of temperate and tropical grasses. Proc. XI Inter. Grassl. Cong. pp. 719722. Surfers Paradise, Queensland.

Moore, J.E., J.C. Burns, A.C. Linnerud and R.J. Monroe. 1980. Relationships between the properties of southern forages and animal response: preliminary report on regional project S-45. Proc. 37th Southern Pasture and Forage Crop Improvement Conf., Nashville, TN. pp. 19-36.

Moore, J.E. and G.O. Mott. 1973. Structural inhibitors of quality in tropical grasses. In: A.G. Matches (ed.). Anti-Quality Components of Forages. pp. 53-98. CSSA Special Publ. No. 4, Madison, WI.

Moore, J.E., L.E. Sollenberger, G.E. Morantes and P.T.Beede. 1987. Canopy structure of Aeschynomene americana-Hemarthria altissima pastures and ingestive behavior of cattle. In: F.P. Horn, J. Hodgson, J.J. Mott and R.W. Brougham (eds.). Grazing Lands Research at the Plant-Animal Interface. pp. 93-114. Winrock International, Morrilton, AR.

Morris, R.J., R.H. Fox and G.A. Jung. 1982. Growth, P uptake, and quality of warm and cool-season grasses on a low available $P$ soil. Agron. J. 74:125-129. 
Nelson, B.D. 1980. Sources of variation in the in vitro digestion of southern forages. Proc. 37th Southern Pasture and Forage Crop Improvement Conf., Nashville, TN. pp. 37-47.

Newell, L.C. and W.J. Moline. 1978. Forage quality evaluations of twelve grasses in relation to season for grazing. Univ. of Nebraska Agric. Expt. Sta. Res. Bull. 283.

Norton, B.W. 1982. Differences between species in forage quality. In: J.B. Hacker (ed.). Nutritional Limits to Animal Production from Pastures. pp. 89-110. Commonwealth Agric. Bureaux, Farnham Royal, UK.

NRC. 1976. Nutrient requirements of beef cattle. 5th revised ed. National Academy of Sciences, Washington, D.C.

NRC. 1984. Nutrient requirements of beef cattle. 6th revised ed. National Academy Press, Washington, D.C.

Olubajo, F.D., P.J. Van Soest and V.A. Oyenuga. 1974. Comparison and digestibility of four tropical grasses grown in Nigeria. $\mathrm{J}$. Anim. Sci. 38:149-153.

Pacheco, M.E., R.D. Brown and R.L. Bingham. 1983. Nutritive value and intake of Kleberg bluestem by beef cattle. J. Range Manage. 36:222-224.

Payne, W.J.A. 1966. Nutrition of ruminants in the tropics. Nutr. Abst. Rev. 36:653-670.

Playne, M.J. 1978. Differences between cattle and sheep in their digestion and relative intake of a mature tropical grass hay. Anim. Feed Sci. Tech. 3:41-45.

Poppi, D.P., D.J. Minson and J.H. Ternouth. 1981. Studies of cattle and sheep eating leaf and stem fractions of grasses. 1 . The voluntary intake, digestibility and retention time in the reticulo-rumen. Aust. J. Agric. Res. 32:99-108.

Prigge, E.C., M.J. Baker and G.A. Varga. 1984. Comparative digestion, rumen fermentation and kinetics of forage diets by steers and wethers. J. Anim. Sci. 59:237-242.

Rees, M.C., D.J. Minson and F.W. Smith. 1974. The effect of supplementary and fertilizer sulfur on voluntary intake, digestibility, retention time in the rumen and site of digestion of pangola grass in sheep. J. Agric. Sci. (Camb.) 82:419-422. 
Reid, J.T., W.K. Kennedy, K.L. Turk, S.T. Slack, G.W. Trimberger and R.P. Murphy. 1959. Effect of growth stage, chemical composition, and physical properties upon the nutritive values of forages. J. Dairy Sci. 42:567-571.

Reid, R.L. 1980. Relationship between phosphorus nutrition of plants and the phosphorus nutrition of animals and man. In: F.E. Khasawneh, E.C. Sample and E.J. Kamprath (eds.). The Role of Phosphorus in Agriculture. pp. 847-886. Am. Soc. Agron., Crop Sci. Soc. Am., Soil Sci. Soc. Am. Madison, WI.

Reid, R.L. and D.J. Horvath. 1980. Soil chemistry and mineral problems in farm livestock. A review. Anim. Feed Sci. Tech. 5:95-167.

Reid, R.L. and G.A. Jung. 1974. Effects of elements other than nitrogen on the nutritive value of forage. In: D.A. Mays (ed.). Forage Fertilization. pp. 395-435. Am. Soc. Agron., Crop Sci. Soc. Am., Soil Sci. Soc. Am. Madison, WI.

Reid, R.L. and G.A. Jung. 1982. Problems of animal production from temperate pastures. In: J.B. Hacker (ed.). Nutritional Limits to Animal Production from Pastures. pp. 21-43. Commonwealth Agric. Bureaux, Farnham Royal, UK.

Reid, R.L. and T.J. Klopfenstein. 1983. Forages and crop residues : quality evaluation and systems of utilization. J. Anim. Sci. 57, Suppl. 2:534-562.

Reid, R.L. and G.A. Jung. 1985. Sward utilization in warm seasoncool season grass grazing systems in the northeast United States. Proc. XV Inter. Grassl. Cong. pp. 1111-1113. Kyoto, Japan.

Reid, R.L., G.A. Jung, W.L. Stout and T.S. Ranney. 1987. Effects of varying zinc concentrations on quality of alfalfa for lambs. $J$. Anim. Sci. 64:1735-1742.

Reid, R.L., G.A. Jung and W.V. Thayne. 1988. Relationships between nutritive quality and fiber components of cool season and warm season forages: a retrospective study. J. Anim. Sci. 66:1275-1291.

Reid, R.L., A.J. Post and F.J. Olsen. 1979. Chemical composition and quality of tropical forages. West Virginia Univ. Agric. and For. Expt. Sta. Bull. 669T. 
Reid, R.L., A.J. Post, F.J. Olsen and J.S. Mugerwa. 1973. Studies on the nutritional quality of grasses and legumes in Uganda. I. Application of in vitro digestibility techniques to species and stage of growth effects. Trop. Agric. (Trinidad) 50:1-15.

Roughan, P.G. and R. Holland. 1977. Predicting in vivo digestibilities of herbages by exhaustive enzyme hydrolysis of cell walls. J. Sci. Food Agric. 28:1057-1064.

Rountree, B.H., A.G. Matches and F.A. Martz. 1974. Season too long for your grass pasture? Crops and Soils 26(7):7-10.

SAS. 1985. SAS User's Guide : Statistics. Statistical Analysis System Institute Inc., Cary, NC.

Shaw, N.H. and W.W. Bryan (ed.). 1976. Tropical Pasture Research - Principles and Methods. Commonwealth Agric. Bureaux, Farnham Royal, UK.

Steel, R.G.D. and J.H. Torrie. 1980. Principles and Procedures of Statistics. McGraw-Hill Book Co., New York.

Stobbs, T.H. 1971. Quality of pasture and forage crops for dairy production in the tropical regions of Australia. I. Review of the literature. Trop. Grassl. 5:159-170.

Stobbs, T.H. 1973. The effect of plant structure on the intake of tropical pasture. II. Differences in sward structure, nutritive value, and bite size of animals grazing Setaria anceps and Chloris gayana at various stages of growth. Aust. J. Agric. Res. 24:821-829.

Stobbs, T.H. 1976. Beef production from sown and planted pastures in the tropics. In: A.G. Smith (ed.). Beef Cattle Production in Developing Countries. pp. 164-183. Centre for Trop. Vet. Med., Univ. of Edinburgh.

Taylor, R.W. and D.W. Allinson. 1981. Nutritive evaluation of warmseason grasses in Connecticut. Storrs Agric. Exp. Sta. Research Report 70.

Ternouth, J.H., D.P.Poppi and D.J. Minson. 1979. The voluntary food intake, ruminal retention time and digestibility of two tropical grasses fed to cattle and sheep. Proc. Nutr. Soc. Aust. 4:152.

Tilley, J.M.A. and R.A. Terry. 1963. A two stage technique for in vitro digestion of forage crops. J. Brit. Grassl. Soc. 18:104-111. 
't Mannetje, L. 1974. Relations between pasture attributes and liveweight gains on a subtropical pasture. Proc. XII Inter. Grassl. Cong., pp. 299-304. Moscow, U.S.S.R.

't Mannetje, L. 1982. Problems of animal production from tropical pastures. In: J.B. Hacker (ed.). Nutritional Limits to Animal Production from Pastures. pp. 67-85. Commonwealth Agric. Bureaux, Farnham Royal, UK.

Van Soest, P.J. 1965. Symposium on factors influencing the voluntary intake of herbage by ruminants : voluntary intake in relation to chemical composition and digestibility. J. Anim. Sci. 24:834-843.

Van Soest, P.J. 1982. Nutritional Ecology of the Ruminant. O \& B Books, Inc., Corvallis, OR.

Vogel, K.P., R. Britton, H.J. Gorz and F.A. Haskins. 1984. In vitro and in vivo analyses of hays of switchgrass strains selected for high and low in vitro dry matter digestibility. Crop Sci. 24:977-980.

Vogel, K.P., C.L. Dewald, H.J. Gorz and F.A. Haskins. 1985. Improvement of switchgrass, indiangrass, and eastern gamagrass - current status and future. Proc. 38th Meeting of Society for Range Management. pp. 159-170.

Voigtländer, G. and W. Kühbauch. 1978. Factors constraining animal production in grazing management. Proc. 7th General Meeting European Grassl. Fed., Ghent, 4.3-4.27.

Vona, L.C. 1982. Nutritive value of warm season grass hays. M.S. Thesis, West Virginia University, Morgantown.

Vona, L.C. 1986. Use of natural carbon isotope ratios to determine diet selection of animals grazing cool and warm season grasses. Ph.D. Dissertation, West Virginia University, Morgantown.

Vona, L.C., G.A. Jung, R.L. Reid and W.C. Sharp. 1984. Nutritive value of warm-season grass hays for beef cattle and sheep. J. Anim. Sci. 59:1582-1593.

Ward, M.G., J.K. Ward, B.E. Anderson, K.P. Vogel, R. Britton, F.A. Haskins and H.J. Gorz. 1984. Effects of switchgrass digestibility on animal performance. J. Anim. Sci. 59(Suppl.1)(Abst.)385:303. 
Wedin, W.F. and W. Friehling. 1978. Smooth bromegrass vs switchgrass for midsummer pasture. pp. 9-11. Ann. Prog. Rep. 1977. Iowa State Univ. ORC 77-10.

Wilson, J.R. 1982. Environmental and nutritional factors affecting herbage quality. In: J.B. Hacker (ed.). Nutritional Limits to Animal Production from Pastures. pp. 111-131. Commonwealth Agric. Bureaux, Farnham Royal, UK.

Wilson, J.R. 1984. Tropical pastures. In: C.J. Pearson (ed.). Control of Crop Productivity. pp. 185-197. Academic Press, London.

Wilson, J.R. 1985. An interdisciplinary approach for increasing yield and improving quality of forages. Proc. XV Inter. Grassl. Cong. pp. 49-55, Kyoto, Japan.

Wilson, J.R. and K.P. Haydock. 1971. The comparative response of tropical and temperate grasses to varying levels of nitrogen and phosphorus nutrition. Aust. J. Agric. Res. 22:573-587.

Wilson, J.R. and D.J. Minson. 1980. Prospects for improving the digestibility and intake of tropical grasses. Trop. Grassl. 14:253-259. 
[Blank Page in Original Bulletin] 
[Blank Page in Original Bulletin] 


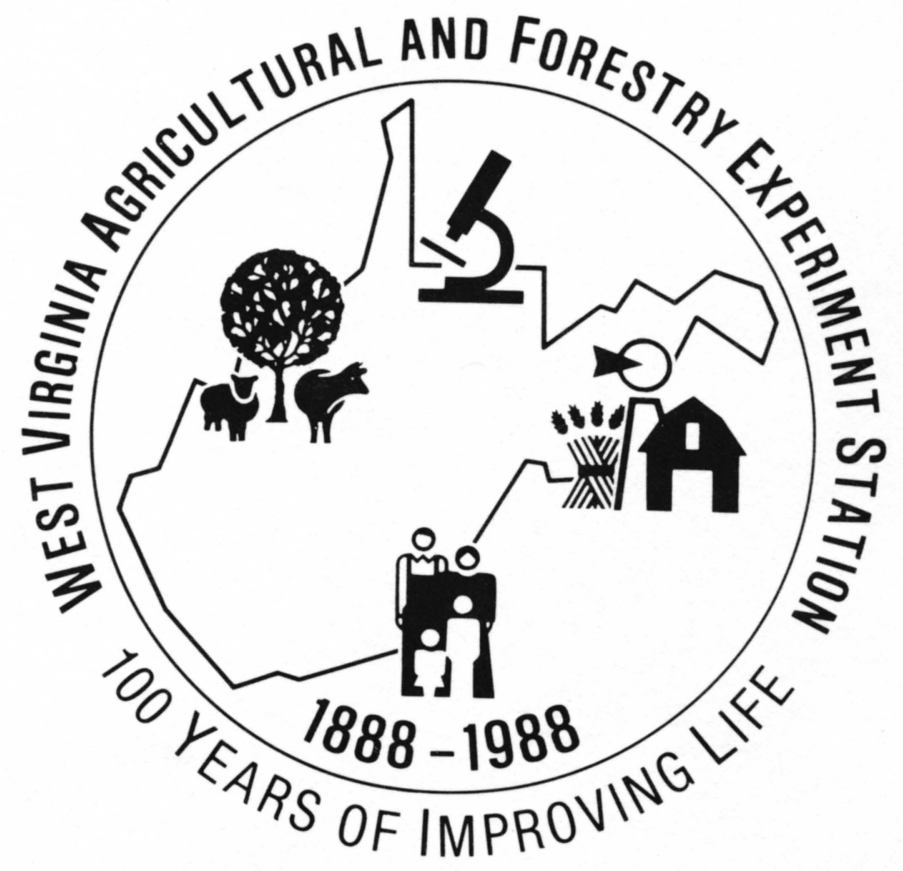

